\title{
International Patent Protection and Trade: Transaction-Level Evidence
}

Gaétan de Rassenfosse

Marco Grazzi

Daniele Moschella Gabriele Pellegrino

March 2020

Innovation and Intellectual Property Policy Working Paper series no. 8

Available at: https://ideas.repec.org/p/iip/wpaper/8.html 


\title{
International Patent Protection and Trade: Transaction-Level Evidence*
}

\author{
Gaétan de Rassenfosse ${ }^{1}$, Marco Grazzi ${ }^{2}$, Daniele Moschella ${ }^{3}$, and \\ Gabriele Pellegrino ${ }^{1}$ \\ ${ }^{1}$ College of Management of Technology, Ecole Polytechnique Fédérale de Lausanne, \\ Switzerland. \\ ${ }^{2}$ Department of Economic Policy, Università Cattolica del Sacro Cuore, Milano, Italy. \\ ${ }^{3}$ Institute of Economics \& EMbeDS, Scuola Superiore Sant'Anna, Pisa, Italy.
}

\begin{abstract}
This paper investigates the extent to which international trade hinges on patents. We analyze the export and patenting activities of the universe of French exporting firms over the period 2002-2011. The noticeable feature of our study is that we observe export and patenting activities worldwide and at the product level. We exploit how heterogeneity of patent coverage across (and within) product-country relates to exports. We find a patent premium of at least 10 percent, which is mainly associated with a quantity effect. A modest price effect emerges in specific sectors, notably pharmaceuticals.
\end{abstract}

Keywords: Export, Patents, Products, Intellectual property rights, Innovation

JEL classification: D22, F10, F14, O30, O34

*Acknowledgments. This work has been partly supported by the European Commission under the H2020, GROWINPRO, Grant Agreement 822781. This work is also supported by a public grant overseen by the French National Research Agency (ANR) as part of the 'Investissements d'avenir' program (reference: ANR-10-EQPX-17, Centre d'accès sécurisé aux données, CASD). This paper has benefited from comments of participants at SETC, Cagliari (September 2019); Università Cattolica, Milano (October 2019), and University of Maastricht (December 2019). We are also indebted to Andrew B. Bernard, Bruno Cassiman, Paola Conconi, Bronwyn H. Hall, and Fabio Montobbio for insightful comments. 


\section{Introduction}

A wealth of evidence supports the view that intellectual property (IP) rights play a central role in international trade. Evidence exists both at the country-industry level and at the firm level. Regarding the former, one of the first relevant works is Soete (1981), which shows a close relationship between technological performance, as proxied by patenting activity, and export performance, as proxied by export market shares, among OECD countries and across several sectors (see also Soete, 1987, and the related discussion in Dosi et al., 2015). An important stream of follow-on research has investigated the nature of such technological factors both at the country level (Fagerberg, 1988; Amendola et al., 1993) and at the country-industry level (Dosi et al., 1990; Amable and Verspagen, 1995; Landesmann and Pfaffermayr, 1997; Wakelin, 1998b; Carlin et al., 2001; Laursen and Meliciani, 2010).

Firm-level evidence on the effect of innovation on export usually relies on survey data, such as the Community Innovation Survey in Europe, in works including Wakelin (1998a), Castellani and Zanfei (2007), Cassiman et al. (2010), Van Beveren and Vandenbussche (2010), and Dosi et al. (2015). A more recent stream of work has exploited administrative data, by matching firm-level data on trade to patent data, including Dosi et al. (2015), Coelli et al. (2016), and Aghion et al. (2018).

All the contributions singled out above share the same perspective on the phenomenon of interest. They posit that patents (as well as other measures of innovation) are an inherent expression of superior capabilities that are conducive to better performance in international markets. At the firm level, this perspective is also very much in tune with recent theoretical models of international trade that predict the self-selection of more productive firms into the export market (see Melitz, 2003; Bernard et al., 2007b, among many others). It is therefore not surprising to find a much higher propensity to export among patenting firms compared to non-patenting ones.

At the same time, there exists at least another concurrent and complementary perspective on the effects of IP on trade that has taken on a more institutional perspective. It shows that a strengthening of IP rights in a country leads to more exports to that country (Maskus and Penubarti, 1995; Smith, 1999; Ivus, 2010; Palangkaraya et al., 2017; Lin and Lincoln, 2017). Extant studies predominantly use industry-level export data, although more recent works have exploited firmlevel data. As far as we can ascertain, Lin and Lincoln (2017) is the first study to exploit a matched firm level dataset on exports and patents. They show that patenting firms are more likely to export to countries that went through a strengthening of IP protection.

The finding that IP institutions enable international trade could arise from two mechanisms that are not mutually exclusive but that have entirely different policy implications. First, an increase in the strength of IP protection may lead to technological upgrading by local firms, which in turns is conducive to international trade. Previous studies have shown that the patent system stimulates economic growth (Gould and Gruben, 1996; Hu and Png, 2013) and affect R\&D incentives (Arora et al., 2008). This mechanism is thus primarily about 
stronger patent rights improving readiness by local firms to use technologyintensive goods, which leads to more international trade. Second, an increase in the strength of protection may provide the necessary guarantee for exporting firms to start selling in the target market. Indeed, patent protection gives the right to exclude others from making, using and selling the patented technology in the markets that are covered by the patent. Patenting is thus key to securing appropriation, at least in certain industries (Teece, 1986; Cohen et al., 2000a).

As far as we can ascertain, extant studies do not identify which mechanism is at play. This gap in knowledge is due to the fact that, without exceptions, all studies are silent on whether the exported goods are protected by patents in the export markets. As discussed, the literature suggests rationales for both mechanisms. However, it also raises skepticism regarding their potential importance. For instance, regarding the second mechanism, the literature emphasizes that other appropriation mechanisms than patents exist (Cohen et al., 2000b; Dosi et al., 2006; Hall et al., 2014; Sampat, 2018), which can be superior to patents in some contexts.

We take one step towards filling this gap by providing evidence related to the second mechanism. The analysis is made possible thanks to the fact that we observe the international patenting activity of firms at the country-product level. ${ }^{1}$ Indeed, a corollary of the second mechanism is that firms will apply for a patent in the new export country for the particular product(s). We seek to understand the role of patenting on firms' exports by documenting how heterogeneity of patent coverage at the country (and product-country) level relates to trade. We exploit two fundamental sources of cross-sectional heterogeneity: firm: a given product exported by two firms in a given country (where the product is protected by one firm but not by the other); and country: a given product by a given firm exported in two countries (where the product is protected in one country but not in the other). Furthermore, we also exploit the time dimension of our data by observing changes in patent protection status over time for a given product by a given firm in a given country.

The empirical analysis proceeds in two steps. First, it investigates whether the decision to file for patents in a country is associated with a higher likelihood of exporting to that country. The strength of the relationship between patenting and export will be an indication of the importance of the second mechanism. Second, the analysis investigates how patent protection in a country is associated with the levels of exports in that country, also considering quantity and price, as proxied by unit values. This part of the analysis will allow us to better understand the exact role that patents play in the export decision.

We find that firms are more likely to start exporting to a country if they have also recently filed a patent in that country. The estimates suggest that patenting in a country is associated with a 3-percentage points increase in the probability to export in that country. We also find that firms have higher export values in countries with active patent protection by about 10 percent. This result holds with firm-product-country fixed effects as well as under a range of alternative

1 As explained in detail in Section 2, we use the HS6 commodity classification, which relates to product categories. We sometimes use the term 'product' for the sake of simplification. 
specifications. All specifications lead to the conclusion that the premium in export value associated with patents is driven by export quantities rather than by unit values. In other words, exporting firms export larger quantities in countries with patent protection but they do not seem to charge higher prices. We interpret this finding as evidence of the fact that firms value foreign patent protection for the legal security that it brings rather than for the possibility to set monopoly prices. One exception is pharmaceutical firms, for which we find that patents are associated with greater unit value - and where patents are known to confer a strong protection against imitation (see, e.g., Mansfield, 1986; Cohen et al., 2000b; Duggan et al., 2016).

\section{Data and descriptive statistics}

\subsection{Dataset construction}

We construct our dataset using two main types of firm-level data, namely export data and patent data.

\section{Export data}

Concerning export data, we rely on transaction-level exports recorded by the French customs office (Direction Générale des Douanes et des Droits Indirects, DGDDI). ${ }^{2}$ The dataset contains detailed information on export flows for each year from 2002 to 2011 for all French exporters. Each exporter is identified by a unique official identification number (SIREN code). The dataset includes information on export value, export quantity, country of destination, and an 8-digit product code following the European Union's Combined Nomenclature (CN8).

Because the last two digits of this code might change from year to year, we aggregate products at the 6-digit level, which corresponds to the international Harmonized System (HS6) trade classification. The HS classification is the standard for measuring trade flows at the finest level of disaggregation. Note that while the HS unequivocally identifies a given product category, more than one variety might fall within a given HS6 class. For the sake of simplicity, we will sometimes refer to HS6 as products, but note that what we are actually capturing is a category of products. The HS classification is revised every five years. Therefore, in order to have a unique product classification scheme throughout the period, we have relied on a concordance table provided by the World Bank. This table maps the 2007 classification to the 2002 classification. ${ }^{3}$ We have used the 2002 HS classification as the main classification - this will prove useful when linking products to patents, as explained further below.

Table 1 reports descriptive statistics for the 2011 cross-section of exporters. There is a total of $1,955,535$ observations in that year (not reported), which cor-

2 The data are directly provided to researchers by the DGDDI upon the approval of a research proposal by the Comité du Secret Statistique.

3 Concordance tables are available at https://wits . worldbank.org/product_concordance. html 
Table 1: A slice of the dataset, year 2011

\begin{tabular}{|c|c|c|c|c|c|c|}
\hline & \multirow{2}{*}{$\begin{array}{l}\text { Exporters } \\
\text { (1) }\end{array}$} & \multirow{2}{*}{$\begin{array}{l}\text { Patentees } \\
\text { (2) }\end{array}$} & \multicolumn{4}{|c|}{$\begin{array}{l}\text { Exporters with patents } \\
\text { Levels of matching }\end{array}$} \\
\hline & & & $\begin{array}{l}\text { Firm } \\
(3)\end{array}$ & $\begin{array}{l}\text { Firm-country } \\
(4)\end{array}$ & $\begin{array}{l}\text { Firm-product } \\
(5)\end{array}$ & $\begin{array}{l}\text { Firm-product-country } \\
(6)\end{array}$ \\
\hline \#Firms & 92,165 & 8,331 & 4,251 & 3,663 & 3,115 & 2,596 \\
\hline \#Patents & . & 81,774 & 63,401 & 58,979 & 53,519 & 48,954 \\
\hline$\# \mathrm{CPC}$ & . & 628 & . & . & 547 & 538 \\
\hline \#Products & 4,182 & . & 3,748 & 3,621 & 2,878 & 2,692 \\
\hline \#Countries & 230 & 86 & 222 & 72 & 219 & 72 \\
\hline Obs. with patents(\%) & . & . & 21.8 & 13.5 & 9.89 & 5.54 \\
\hline Exports with patents(\%) & . & . & 41.9 & 33 & 34.8 & 27.4 \\
\hline
\end{tabular}

Notes: The table reports basic figures for the dataset of exporters in 2011 (col. 1); the 10-year stock of patent applications worldwide (col. 2); the matched observations over the two datasets at the firm level (col. 3), firm-country level (col.4), firm-product level (col. 5), firm-product-country level (col. 6).

respond to different transactions at the firm-product-destination level. Column (1) shows that 92,165 firms account for these transactions, and they exported a total of 4,128 different product categories (at the 6-digit level) to 230 different destination countries. We discuss the rest of the table in the next section.

\section{Patent data}

Regarding patent data, we relied on two data sources. We obtained information on patent applications filed by French firms at the French patent office (Institut National de la Propriété Industrielle, INPI) and at the European Patent Office (EPO). These data were provided to us by INPI and are available since 1993, well before the start of our export data. ${ }^{4}$ Because patents are jurisdictional rights, patents granted by INPI are valid only in France, whereas patents filed at the EPO are valid potentially throughout Europe. ${ }^{5}$ Information on whether patent protection is extended to other countries comes from the official register of each national patent office across the world. This information is available in the PATSTAT database, which provides bibliographical and legal status data for patent offices worldwide (de Rassenfosse et al., 2014). ${ }^{6}$ Using the French patent document numbers, we could identify all the patent applications belonging to the same patent family across 90 patent offices. ${ }^{7}$ We have also used the PATSTAT database to obtain bibliographic data about the patents, including the priority year in the patent family and the technological class(es) to which patents pertain. We have used the Cooperative Patent Classification (CPC) codes, which is a classification of technologies jointly managed by the European Patent Office and the U.S. Patent and Trademark Office.

4 Obtaining data from INPI required signing a license agreement to reuse the data. The data were delivered free of charge through FTP access in zipped XML files.

5 Once a patent is granted by the EPO, it must be validated in each country where protection is desired. The vast majority of EPO patents are validated in Germany, the United Kingdom and France.

6 The PATSTAT database can be accessed via https://www.epo.org/ searching-for-patents/business/patstat.html.

7 A family of patents is a set of patent applications covering the same invention in different countries (Martínez, 2010). 
An important choice in the data collection design relates to the use of granted patents versus patent applications (which include granted patents and pending patents). Granted patents correspond to patents that are issued by the patent office after having successfully gone through the examination process, whereas pending patents are patents awaiting examination and, ultimately, issuance. We have opted for the use of patent applications. Although it is only once a patent is granted that firms can seek damages in case of infringement, pending patents already offer some level of protection. Indeed, any infringement that occurs between the patent application's filing date and the grant date can serve as cause for a legal claim of action. Hence the phrase "patent pending" marked on products or mentioned in advertisements to provide notice to potential infringers. As a matter of fact, many products are commercialized with a pending patent, and Section 2.3 provides evidence supporting this claim. Another argument in favor of using patent applications instead of granted patents relates to information disclosure. A firm may still want to export in a country even if the patent is refused in that country because the technology has been disclosed through the patent document. Competitors can freely observe the invention by reading the patent document, so why would the innovator give away foreign markets by not exporting? Finally, in case only granted patents have an effect on trade, the inclusion in our sample of patent applications that will ultimately be refused would lead to conservative estimates. ${ }^{8}$

Another design choice relates to how long we should assume that the invention underlying a patent generates an economic benefit. One way to answer this question would be to observe the legal status (i.e., active or lapsed/expired) of each granted patent in each jurisdiction - with the assumption that patents generate economic benefits throughout their period of validity, and for a maximum of 20 years. Using information on legal status would conflict with our choice of using patent applications, because this information is only available for granted patents. Furthermore, collecting such information would be extremely costly given the large number of jurisdictions that we are working with. Therefore, we need to assume an average 'useful' life for patent applications. Estimates suggest that the average lifetime of patents is about ten years (e.g., de Rassenfosse and Jaffe, 2018). Accordingly, we consider a 10-year stock of patents for each exporting firm. That is, the number of patents of firm $f$ (for product $p$ ) in country $c$ in year $y$ is computed as the sum of the number of patents filed from year $y$ to year $y-9$, using the priority year in the patent family, by that firm in that country (for that product).

Column (2) of Table 1 shows that the 10-year stock of patent applications in 2011 consisted in 81,774 patent applications worldwide by 8,331 French firms exporting in that year. These applications cover almost the whole set of technological classes (628 CPC codes at 4-digit level out of 641 total CPC codes), and belong to families that cover 86 different countries.

8 In that case, we do not expect the (downward) bias to be too strong. Multi-jurisdictions patent families are particularly valuable (Harhoff et al., 2003) and firms therefore have an incentive to push for a grant. Evidence by Guellec and van Pottelsberghe (2000) suggests that international patent applications are more likely to be granted than single-country applications. 


\section{Linking export data with patent data}

Export and patent data have two features in common: the SIREN identification code for firms; and the country identification code for export destinations and patent offices. We are thus able to merge the datasets at the firm level and at the firm-country level. Among patenting exporters, 50 percent of firms export more than eight products whereas the median number of products among all exporters is two. The difference is not surprising, given that the size distribution of patentees is much more skewed than the general size distribution of exporters. But the figure suggests that it is worth considering the product dimension when analysing the relationship between patenting and export performance. We use a concordance table between product codes and patent technological classes to merge the dataset at the product level. Thus, we have a total of four levels of analysis: firm, firm-country, firm-product, and firm-product-country. We discuss each level in turn.

First, regarding the firm-level match, we link all patent applications from a firm (no matter in which countries they were applied for) to all its transactions. This type of merge is what is usually done in the literature on firm-level analysis of exports and patents (see, among the most recent contributions, Coelli et al., 2016; Lin and Lincoln, 2017; Aghion et al., 2018). In our case, this merge leads to about 22 percent of transactions covered by a patent application. These transactions account for around 42 percent of total export value in 2011, see column (3) of Table 1. About 5 percent of firms $(4,251$ out of 92,165$)$ account for these exports, and they jointly own a 10-year stock of 63,401 patent applications in $2011 .^{9}$

Second, regarding the firm-country level match, we link all patent applications from a firm in a specific country to all its export transactions to that country. This match produces the figures reported in Table 1, column (4). The share of transactions covered by a patent decreases from 22 percent to 13.5 percent. Interestingly, the share of export value accounted for by a patent decreases less than proportionally, going from 42 percent to 33 percent. Lower coverage rates with the geographical matching $(72$ countries $)$ are due to the fact that firms holding a patent export to a wide range of countries (222) and file for patents in 86 over the 90 countries for which we have patent data. ${ }^{10}$ Conversely, firms sometimes file for patents in countries to which they do not export (in 2011) this fact explains the drop in the number of applications matched, from 63,401 to 58,979 . Although this may seem surprising, there are four logical explanations for such cases: the firm has not yet exported in the country; it no longer exports there; it temporarily suspended export; or it has never intended to export (but patent protection is needed, e.g., to protect the manufacturing process in that

9 Notice that the difference between the number of patents in columns (2) and (3) is partly explained by the fact that firms applying for a patent over the period 2002-2011 may not be exporting in 2011 but in some previous year. If we match patents applications with firms that have exported in at least one year over the period 2002-2011, we match 73,834 patent applications.

${ }^{10}$ There are 204 patent offices in the world according to WIPO. PATSTAT covers 114 patent offices and contains data for all major patent offices.

Source: https://www.wipo.int/directory/en/urls.jsp 
country).

Third, regarding the firm-product match, we have exploited the concordance table developed by Lybbert and Zolas (2014). The authors propose a probabilistic crosswalk between the $2002 \mathrm{HS}$ classification at the 6-digit level and CPC codes at the 4-digit level, so-called ALP crosswalk. ${ }^{11}$ We use the crosswalk to assign, for each product, the CPC codes with the corresponding probabilistic weights. We then merge the resulting data with patent applications using both their SIREN and CPC codes. As a result, each product may be linked to one or more patents with the corresponding weights. Table 1, column (5), presents the descriptive statistics using the unweighted match that we will use in the rest of the paper, i.e., we consider a firm-product or a firm-product-country matched to a patent using a binary indicator $(0 / 1)$, where 1 denotes a probabilistic weight greater than zero. The share of transactions covered by a patent drops from 22 percent of column (3) to around 10 percent, whereas the share of export value accounted for by patents decreases much less, going from 42 percent to 35 percent. Similarly to what we observed at the firm-country level, lower coverage rates are due to the fact that firms holding a patent export a wide range of products $(3,748)$, but their patents' technological classes (proxied by CPC codes) are related only to a subset of such product categories $(2,878)$ - thus 870 product categories are not covered by patents, most likely due to the fact that patent protection is not an effective means of appropriation in such cases. On the other hand, firms' patents also cover technological classes that are not related to their product portfolio. ${ }^{12}$

Fourth, regarding the firm-product-country match, we further impose that the patent application related to a specific product exported in country $c$ is filed to patent office $c$. Table 1, column (6) presents the descriptive statistics. As expected, this additional level of matching further reduces the share of transactions covered by a patent (around 5.5 percent) and the share of export value accounted for by a patent (27.4 percent). The number of countries and the number of products covered by a patent do not change significantly with respect to columns (4) and (5), although there is a slight decline in the number of patent applications matched with respect to column (5). This difference means that in some cases a transaction is covered by a patent relevant for the country but not for the product exported or that a product covered by a patent is exported also to country in which it is not covered by a patent.

\section{$2.2 \quad$ Descriptive statistics}

Table 2 reports the breakdown of patents across sectors classified according to the OECD definition of technology intensity. In columns (1)-(3) (panel 'Firm'), we assign firms to sectors based on their most important product (highest export

11 The concordance tables can be downloaded at https://sites.google.com/site/nikolaszolas/PatentCrosswalk.

12 There are, again, four potential explanations for this pattern: the firm has not yet exported the product; it no longer exports it; it temporarily suspended export; or it has never intended to export (or even produce) - this last explanation is possibly related to firms that "know more than they do," see Patel and Pavitt (1997) and Dosi et al. (2017). 
Table 2: Breakdown of patent applications across sectors, years 2002-2011

\begin{tabular}{|c|c|c|c|c|c|c|c|}
\hline & $\begin{array}{r}\text { No obs. } \\
(1)\end{array}$ & $\begin{array}{l}\text { Firm } \\
\text { mean } \\
(2)\end{array}$ & $\begin{array}{r}\text { process } \\
(3)\end{array}$ & $\begin{array}{r}\text { No obs. } \\
(4)\end{array}$ & $\begin{array}{r}\text { Firm- } \\
\text { mean } \\
(5)\end{array}$ & $\begin{array}{l}\text { roduct } \\
\text { weight } \\
(6)\end{array}$ & $\begin{array}{r}\text { process } \\
(7)\end{array}$ \\
\hline High-tech & 12,986 & 2.35 & 0.22 & 111,749 & 1.30 & 0.46 & 0.19 \\
\hline Medium-high-tech & 25,767 & 1.07 & 0.24 & 167,280 & 1.40 & 0.42 & 0.29 \\
\hline Medium-low-tech & 14,446 & 0.49 & 0.26 & 131,026 & 0.67 & 0.18 & 0.25 \\
\hline Low-tech & 38,966 & 0.09 & 0.24 & 232,624 & 0.12 & 0.05 & 0.20 \\
\hline Total & 92,165 & 0.75 & 0.24 & 642,679 & 0.77 & 0.24 & 0.24 \\
\hline
\end{tabular}

Notes: The table reports the breakdown of patent applications (filed in the period 2002-2011) across sectors classified according to the OECD definition of technology intensity. Columns (1)-(3) report: number of firms, average number of patents per firm, average share of processrelated patents per firm. Columns (4)-(7) report: number of firms-products, average number of patents per firm-product, average weighted number of patents per firm-product, average share of process-related patents per firm-product.

share). As expected, high-tech sectors display the highest average number of patents per firm, 2.35, and the number steadily decreases with the technological intensity of sectors.

Column (3) reports the average share of patents that can be related to a process innovation. We take advantage of the work by Ganglmair et al. (2020) who classified granted U.S. patents into product patents vs. process patents based on their textual content. A total of 55,073 patent applications in our sample are filed at the USPTO over the period 2002-2011, of which 35,847 have been granted. Overall, by extending the information to the patent families, we are able to classify 30,888 patent families out of 63,401 total patents by exporting firms. The average share of process-related patents is around 24 percent, and it is fairly stable across sectors.

Columns (4)-(7) (panel 'Firm-product') report similar statistics for patents matched at the firm-product level using the ALP crosswalk. The average number of patents per firm-product in column (5) increases compared to figures in column (2) for all but the high-tech sector. This pattern is due to the fact that, among multi-product exporters with patents, high-tech products are more likely to be the most important product. Around 29 percent of firm-product pairs with a patent are in high-tech sectors, but this share reaches 35 percent if we consider only the most important product for each firm (not reported in Table 2).

Finally, column (6) reports the weighted number of patents per firm-product, where the weights are taken from the ALP crosswalk, and column (7) reports the average proportion of process-related patents. If we consider the weighted number of patents, high-tech sectors display the highest average, whereas the medium-high-tech sectors show the highest incidence of process-related patents.

The proportions are more heterogeneous at a finer level of classification. Appendix tables A1 and A2 present the distributions of patents per firm and per firm-product across sectors defined at the two-digit level of the HS6 system. In the latter case, the highest average number of patents per firm is in Pharmaceutical Products (4.1), whereas the proportion of process-related patents is as high as 68 percent in vegetable products. 


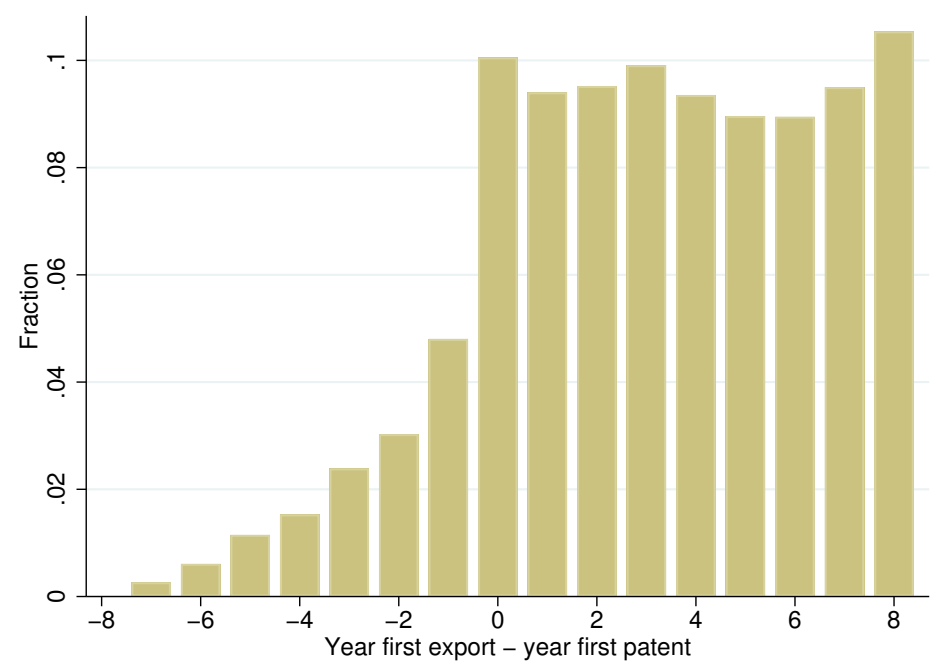

Figure 1: Distribution of the time interval between the first patent and the first export at the firm-product-country level. Patent data from 1996, export data from

2004. Source: our elaborations on the combined dataset

\subsection{The relative timing of patenting and export}

Our data enable us to investigate the relative timing of patenting with respect to exporting. Does patenting tend to anticipate exporting or vice-versa?

The cross-sectional evidence in Table 1 shows that, in 2011, around 5 percent of all trade flows are matched to (at least) one patent at the firm-product-country level. In absolute numbers, this figure corresponds to 106,564 transactions. If we consider the whole period for which trade data are available (2002-2011), a total of 265,001 unique (i.e., not repeated over time) firm-product-country transactions are matched to a patent. Taking advantage of the longest time period available, we investigate whether the patenting activity precedes or follows exporting. To this end, we compute the difference between the year in which an export transaction in a firm-product-country is first detected in the customs data and the year in which we first observe patenting at the firm-product-country triplet. A positive difference provides evidence that patenting activity precedes exporting.

Figure 1 reports the distribution of the time differences between patenting and exporting. We went through the following steps to draw it. First, we set the maximum time span between the first export and the first patent application to eight years. This limit arises from the fact that the stock of patents is computed over a ten-year time interval, and any time difference greater than nine years would be attributed to the arbitrary end of the stock. Accordingly, we consider patent data starting from 1996. Second, as far as the exporting activity is concerned, we only consider transactions from 2004 onward, thus allowing to check whether a given export transaction was already taking place in the first two years (export data are available starting in 2002). These filters limit the resulting set of observations to 118,365 .

Notice, first, that around 90 percent of all observations reported in Figure 1 


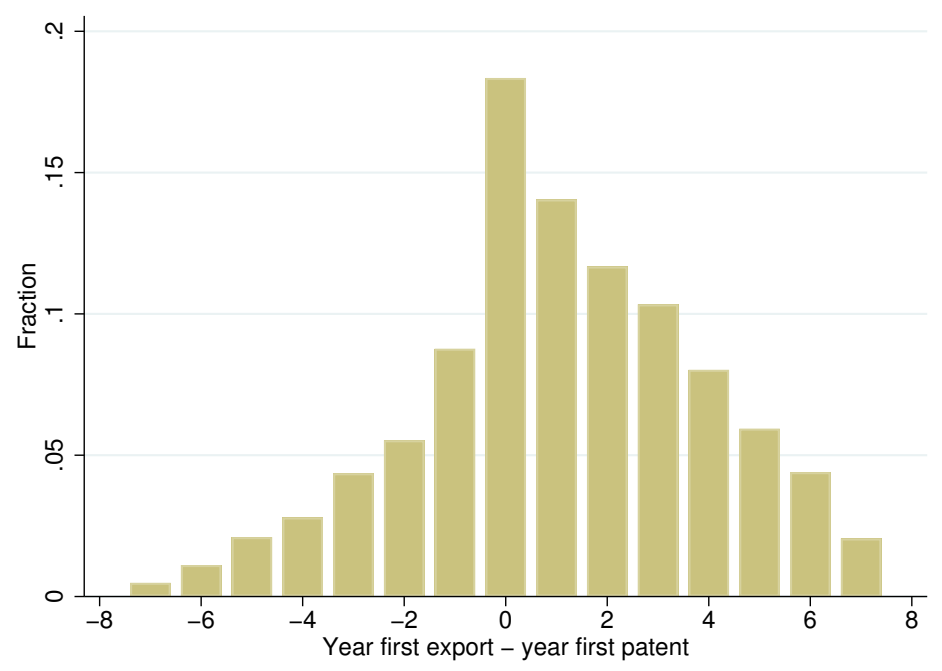

Figure 2: Distribution of the time interval between the first patent and the first export at the firm-product-country level. Patent and export data from 2004. Source: our elaborations on the combined dataset

are between zero and eight; the export activity is therefore largely subsequent to the patent application at the firm-product-country level. There is a clear jump in the distribution at zero. In around 10 percent of the cases firms export to a given product-country destination and do apply for the corresponding patent in the same year.

In Figure 2, we replicate the same exercise but we set the same initial period for patents and exports (2004). This restriction narrows the set of observations to 64,871 . The general message is unchanged: in around 75 percent of the cases, the firm-product-country export triplet is activated during or after a patent application. However, the contemporaneity between export and patent is now dominant compared to Figure 1, concerning around 18 percent of the cases. The decline of the distribution to the right of the zero is a mechanical consequence of the fact that we are leaving out older patentees.

\section{Patents and export destinations}

Table 1, columns (3) and (5), provides evidence that patenting firms usually file for patents in countries to which they export. In this section we explore more in detail the relationship between patents and export destinations. We estimate the correlation between the patenting activity of a firm in a country and exports to that country. To this end, we collapse the original dataset, in which each observation represents an export transaction at the firm-country-product level, to a dataset in which each observation is a transaction at the firm-country level. At this stage, dropping one dimension from the analysis is necessary to make the estimation computationally feasible. In the next sections, when analyzing the relationship between patents and export value, we will resort to a more complete analysis, also considering the product dimension. 
We estimate the following equations:

$$
\begin{aligned}
& D \operatorname{Exp}_{f c t}=a+\beta D \operatorname{Pat}_{f c t}+\theta_{f}+\theta_{c t}+\varepsilon_{f c t} \\
& D \operatorname{Exp}_{f c t}=a+\beta D P a t_{f c t}+\theta_{f c}+\theta_{c t}+\varepsilon_{f c t}
\end{aligned}
$$

where $D E x p_{f c t}$ is a binary variable $(0,1)$ that indicates whether firm $f$ exports to country $c$ in year $t$ and $D P a t_{f c t}$ is a binary variable taking value of 1 if the firm $f$ has a positive 10-year stock of patents in country $c$ at time $t$. In equation (1) we include firm fixed effects $\left(\theta_{f}\right)$ and destination-year fixed effects $\left(\theta_{c t}\right)$. This set of fixed effects is standard in the trade literature and allows us to control for any time invariant firm characteristic and for any destination specific time varying characteristics. The latter includes 'gravity' variables such as the country GDP per capita, and the cyclical component of the demand in the destination country. The set of fixed effects in equation (2) is quite demanding as we include firmdestination fixed effects $\left(\theta_{f c}\right)$, which control for any time invariant characteristic of the firm-destination pair. Therefore, this regression equation exploits the time variation in the patenting status of any firm-destination pair.

We estimate equations (1) and (2) on the sample of firms that have at least one patent in one country in one year. Both specifications involve high-dimensional fixed-effects: around 8,500 firm effects and 2,000 destination-year effects in the first case, and around 1,400,000 firm-destination effects in the second case. We estimated them using the high-dimensional fixed effects estimator developed by Correia (2017) and implemented in the Stata routine reghdfe. ${ }^{13}$

In Table 3, column (1) reports the coefficient from estimating equation (1) on the baseline sample. A within-firm change in the patenting status with respect to a given destination in a given year is associated with a 8.6 percentage point increase in the probability to export to the country in the year. Columns (2) and (4) restrict the sample to firms that never exported in destination $c$ before time $t$. The restriction is made using information on firms that are observed to export in at least two years. In column (2), this restriction allows us to interpret the related coefficient as the increase in probability to add a new export destination in a given year, which amounts to 1.1 percentage points. Columns (3) and (4) report the coefficients from estimating equation (2). In this case, we can interpret the coefficients as saying that a within firm-destination change in patent protection is associated with an increase in the probability to export of 2.6 percentage points, and to an increase in the probability to add a new export destination of 1 percentage point.

\footnotetext{
$\overline{13}$ Notice that the Stata routine reghdfe reports the number of observations effectively used in the estimation. This implies, for example, that when we estimate equation (2), the firmdestination pair with only one observation are not included in the $N$ statistics.
} 
Table 3: Patents and export destinations, 2002-2011

\begin{tabular}{lcccc}
\hline & $(1)$ & $(2)$ & $(3)$ & $(4)$ \\
\hline DPat $_{f c t}$ & $0.086^{* * *}$ & $0.011^{* * *}$ & $0.026^{* * *}$ & $0.010^{* * *}$ \\
& $(0.010)$ & $(0.002)$ & $(0.002)$ & $(0.001)$ \\
\hline Firm FE & Yes & Yes & No & No \\
Country-Year FE & Yes & Yes & Yes & Yes \\
Firm-Country FE & No & No & Yes & Yes \\
$N$ & $14,297,697$ & $10,272,171$ & $14,084,509$ & $10,070,648$ \\
adj. $R^{2}$ & 0.301 & 0.039 & 0.672 & 0.167 \\
\hline
\end{tabular}

Note. The table reports results of regression equations (1) and (2) on the panel firms with at least one patent in one country in one year (column 1 and 3). In column (2) and (4), the sample is restricted to firms that never exported in destination $c$ before time $t$. Robust standard errors clustered at the country level in parenthesis. ${ }^{*} p<0.10,{ }^{* *} p<$ $0.05,{ }^{* * *} p<0.01$

\section{Patents and export value}

\subsection{Cross-sectional analysis}

The previous section showed that there is a relationship between patenting activity and firms adding and maintaining export destinations. In this section, we explore the effects of patenting activity on export value in the observed firmproduct-country flows.

Differently from before, the analysis on export value is not computationally constrained, so we will consider both the country and the product dimension of exporting firms. The dataset contains many different dimensions (firm, country, product and time) and outcome variables (total value of exports, which can be decomposed into total quantity of exports and unit value of exports). The regression analysis methodically peels the various layers of the data, going from a low to a high level of granularity.

As standard in the trade literature (see, for instance, Bernard et al., 2007a), a firm's total exports to a product-country destination is decomposed into extensive (quantity) and intensive margins (unit values):

$$
\ln X_{f p c}=\ln \text { Quantity }_{f p c}+\ln \text { UnitValue }_{f p c}
$$

where $\ln X_{f p c}$ is the $\log$ value (in euro) of exports by firm $f$ in product $p$ to country $c$, Quantity fpc $_{\text {is }}$ the physical quantity (in kilo) of good $p$ exported to country $c$ and UnitValue $_{f p c}$ is the unit value of the transaction.

As explained, we explore the difference in terms of exports, quantity and unit value between observations that are related to patents and observations that are not. Therefore, we exploit cross-sectional variation in the patent status (as summarized by our set of dummies). In particular, we will exploit two sources of heterogeneity, i.e., firm and country. In the first set of regressions, we explore 
the difference, within a destination-product market, between firms that have a patent and firms that do not (see Tables $4,5,6$ ). In the second set of regressions, we explore the difference, within a firm-product variety, between countries where the variety is protected and countries where it is not (Table 7 ). We will perform this analysis for three cross-sections of years, namely 2002, 2007 and 2011. (We will move to panel estimates in Section 4.2.) We estimate several regression equations having the following general form:

$$
\ln Y_{f p c}=a+\beta D P a t+\theta+\varepsilon_{f p c}
$$

where $\ln Y_{f p c}$ denotes the logarithm of, alternatively, total value, quantity and unit value of the firm's exports in the country-product pair, DPat is a dummy for patent coverage, and $\theta$ a set of fixed effects. We measure DPat at different levels of granularity, exploiting the matching as in Table 1, columns (3)-(6):

(1) $\mathrm{DPat}_{f}$ is a binary variable taking value 1 if the firm has a positive 10-year stock of patent applications, and 0 otherwise (it is constructed using solely information on the SIREN identification code);

(2) DPat $_{f p}$ is a binary variable taking value 1 if the firm-product pair is matched to a positive 10-year stock of patents, and 0 otherwise (it is constructed using the SIREN code and the ALP crosswalk);

(3) $\mathrm{DPat}_{f c}$ is a binary variable taking value 1 if the firm-country pair is matched to a positive stock, and 0 otherwise (it is constructed using the SIREN identification code and the country code); and

(4) $D_{\text {Pat }} f p c$ is a binary variable taking value 1 if the firm-product-country flow is matched to a positive stock (it is constructed using the SIREN identification code, the country code, and the ALP crosswalk).

We also construct a binary variable, DProcess $s_{f}$, taking value 1 if the firmproduct pair is matched to a positive 10-year stock of patents, in which at least one patent is identified as process-related following Ganglmair et al. (2020).

\section{Firm-level heterogeneity}

Table 4 presents cross-section estimates using the firm and firm-product level patent dummy (variables $D P a t_{f}$ and $D P a t_{f p}$ ). Table 5 adds the country dimension to the patent dummy $\left(D P a t_{f c}\right.$ and $\left.D P a t_{f p c}\right)$. Since the regressions in both Table 4 and Table 5 control for country-product fixed effects, the results capture the difference in export (total value, quantity and unit value) across two firms, selling the same product to the same export destination, where one firm owns a patent protecting the related product category and the other firm does not. This is our firm level source of heterogeneity.

Notice the similarity between columns (1)-(3) of Table 4 and columns (1)-(3) of Table 5. The results suggest that patenting firms enjoy an export premium in the range of $65-106$ percent, ${ }^{14}$ and that much of this premium is associated

\footnotetext{
${ }^{14}$ We use the following formula to compute export premia: $[\exp (\beta)-1] * 100$
} 
Table 4: Across firms, within destination-products markets: firm and firm-product dummy

\begin{tabular}{|c|c|c|c|c|c|c|}
\hline & $\begin{array}{l}(1) \\
\ln X_{f c p t}\end{array}$ & $\begin{array}{c}(2) \\
\ln \text { Quantity }_{f c p t}\end{array}$ & $\begin{array}{c}(3) \\
\ln \text { UnitValue }_{f c p t}\end{array}$ & $\begin{array}{c}(4) \\
\ln X_{f c p t}\end{array}$ & $\begin{array}{c}(5) \\
\ln \text { Quantity }_{\text {fcpt }}\end{array}$ & $\begin{array}{c}(6) \\
\ln \text { UnitValue }_{\text {fcpt }}\end{array}$ \\
\hline \multicolumn{7}{|l|}{2002} \\
\hline DPat $_{f}$ & $\begin{array}{c}0.628^{* * *} \\
(0.034)\end{array}$ & $\begin{array}{c}0.528^{* * *} \\
(0.027)\end{array}$ & $\begin{array}{c}0.100^{* * *} \\
(0.010)\end{array}$ & & & \\
\hline $\operatorname{DPat}_{f p}$ & & & & $\begin{array}{c}1.164^{* * *} \\
(0.087)\end{array}$ & $\begin{array}{c}1.138^{* * *} \\
(0.077) \\
\end{array}$ & $\begin{array}{l}0.027^{*} \\
(0.014) \\
\end{array}$ \\
\hline Country-Product FE & Yes & Yes & Yes & Yes & Yes & Yes \\
\hline Firm FE & No & No & No & No & No & No \\
\hline$N$ & $1,542,699$ & $1,542,699$ & $1,542,699$ & $1,542,699$ & $1,542,699$ & $1,542,699$ \\
\hline $\operatorname{adj} . R^{2}$ & 0.204 & 0.409 & 0.665 & 0.211 & 0.415 & 0.664 \\
\hline$N$ clusters & 212 & 212 & 212 & 212 & 212 & 212 \\
\hline \multicolumn{7}{|l|}{2007} \\
\hline $\mathrm{DPat}_{f}$ & $\begin{array}{c}0.615^{* * *} \\
(0.044)\end{array}$ & $\begin{array}{c}0.459^{* * *} \\
(0.033)\end{array}$ & $\begin{array}{c}0.156^{* * *} \\
(0.013)\end{array}$ & & & \\
\hline $\operatorname{DPat}_{f p}$ & & & & $\begin{array}{c}1.199^{* * *} \\
(0.083) \\
\end{array}$ & $\begin{array}{c}1.107^{* * *} \\
(0.069) \\
\end{array}$ & $\begin{array}{c}0.092^{* * *} \\
(0.016) \\
\end{array}$ \\
\hline \multicolumn{7}{|l|}{2011} \\
\hline DPat $_{f}$ & $\begin{array}{c}0.499^{* * *} \\
(0.042)\end{array}$ & $\begin{array}{c}0.382^{* * *} \\
(0.035)\end{array}$ & $\begin{array}{c}0.117^{* * *} \\
(0.009)\end{array}$ & & & \\
\hline $\operatorname{DPat}_{f p}$ & & & & $\begin{array}{c}1.127^{* * *} \\
(0.077)\end{array}$ & $\begin{array}{c}1.046^{* * *} \\
(0.067)\end{array}$ & $\begin{array}{c}0.081^{* * *} \\
(0.013)\end{array}$ \\
\hline
\end{tabular}

Note. Table reports results of regressions at the firm-product-country level, using data on exports, quantity and unit value for years $2001,2007,2011$. Robust standard errors clustered at country level in parenthesis. ${ }^{*} p<0.10,{ }^{* *}$ $p<0.05,{ }^{* * *} p<0.01$

Table 5: Across firms, within destination-products markets: firm-country and firm-product-country dummy

\begin{tabular}{|c|c|c|c|c|c|c|}
\hline & $\stackrel{(1)}{\ln X_{f c p t}}$ & $\begin{array}{c}(2) \\
\ln \text { Quantity }_{f c p t}\end{array}$ & $\begin{array}{c}(3) \\
\ln \text { UnitValue }_{\text {fcpt }}\end{array}$ & $\begin{array}{c}(4) \\
\ln X_{f c p t}\end{array}$ & $\begin{array}{c}(5) \\
\ln \text { Quantity }_{f c p t}\end{array}$ & $\begin{array}{c}(6) \\
\ln \text { UnitValue }_{\text {fcpt }}\end{array}$ \\
\hline \multicolumn{7}{|l|}{2002} \\
\hline $\operatorname{DPat}_{f c}$ & $\begin{array}{c}0.722^{* * *} \\
(0.034)\end{array}$ & $\begin{array}{c}0.597 * * * \\
(0.030)\end{array}$ & $\begin{array}{c}0.124^{* * *} \\
(0.010)\end{array}$ & & & \\
\hline$D_{P a t} t_{f p c}$ & & & & $\begin{array}{c}1.497^{* * *} \\
(0.087)\end{array}$ & $\begin{array}{c}1.449^{* * *} \\
(0.077)\end{array}$ & $\begin{array}{c}0.048^{* * *} \\
(0.014)\end{array}$ \\
\hline Country-Product FE & Yes & Yes & Yes & Yes & Yes & Yes \\
\hline Firm FE & No & No & No & No & No & No \\
\hline$N$ & $1,542,699$ & $1,542,699$ & $1,542,699$ & $1,542,699$ & $1,542,699$ & $1,542,699$ \\
\hline adj. $R^{2}$ & 0.203 & 0.409 & 0.665 & 0.210 & 0.414 & 0.664 \\
\hline$N$ clusters & 212 & 212 & 212 & 212 & 212 & 212 \\
\hline \multicolumn{7}{|l|}{2007} \\
\hline DPat $_{f c}$ & $\begin{array}{c}0.710^{* * *} \\
(0.043)\end{array}$ & $\begin{array}{c}0.522^{* * *} \\
(0.033)\end{array}$ & $\begin{array}{c}0.188^{* * *} \\
(0.013)\end{array}$ & & & \\
\hline$D_{P a t} f p c$ & & & & $\begin{array}{c}1.493^{* * *} \\
(0.081)\end{array}$ & $\begin{array}{c}1.365^{* * *} \\
(0.066)\end{array}$ & $\begin{array}{c}0.129^{* * *} \\
(0.018)\end{array}$ \\
\hline \multicolumn{7}{|l|}{2011} \\
\hline $\operatorname{DPat}_{f c}$ & $\begin{array}{c}0.615^{* * *} \\
(0.040)\end{array}$ & $\begin{array}{c}0.479 * * * \\
(0.034)\end{array}$ & $\begin{array}{c}0.136^{* * * *} \\
(0.011)\end{array}$ & & & \\
\hline$D_{P a t} f p c$ & & & & $\begin{array}{c}1.424^{* * *} \\
(0.075)\end{array}$ & $\begin{array}{c}1.318^{* * *} \\
(0.065)\end{array}$ & $\begin{array}{c}0.106^{* * * *} \\
(0.015)\end{array}$ \\
\hline
\end{tabular}

Note. Table reports results of regressions at the firm-product-country level, using data on exports, quantity and unit value for years $2001,2007,2011$. Robust standard errors clustered at country level in parenthesis. ${ }^{*} p<0.10,{ }^{* *}$ $p<0.05,{ }^{* * *} p<0.01$ 
Table 6: Across firms, within destination-products markets: taking into account process-related patents, firm-product-country dummy

\begin{tabular}{|c|c|c|c|c|c|c|}
\hline & $\stackrel{(1)}{\ln X_{f c p t}}$ & $\begin{array}{c}(2) \\
\ln \text { Quantity }_{f c p t}\end{array}$ & $\begin{array}{c}(3) \\
\ln \text { UnitValue }_{\text {fcpt }}\end{array}$ & $\begin{array}{c}(4) \\
\ln \stackrel{X}{f c p t}\end{array}$ & $\begin{array}{c}(5) \\
\ln \text { Quantity }_{f c p t}\end{array}$ & $\begin{array}{c}(6) \\
\ln \text { UnitValue }_{\text {fcpt }}\end{array}$ \\
\hline \multicolumn{7}{|l|}{2002} \\
\hline $\begin{array}{l}\text { DPat }_{f p c} \\
\text { DProcess }_{f p} * \text { DPat }_{f p c}\end{array}$ & $\begin{array}{c}1.596^{* * *} \\
(0.090)\end{array}$ & $\begin{array}{c}1.505^{* * *} \\
(0.076)\end{array}$ & $\begin{array}{c}0.092^{* * *} \\
(0.021)\end{array}$ & $\begin{array}{c}1.442^{* * *} \\
(0.080) \\
0.343^{* * *} \\
(0.044)\end{array}$ & $\begin{array}{c}1.346^{* * *} \\
(0.068) \\
0.355^{* * *} \\
(0.051)\end{array}$ & $\begin{array}{c}0.097^{* * *} \\
(0.022) \\
-0.011 \\
(0.014)\end{array}$ \\
\hline $\begin{array}{l}\text { Country-Product FE } \\
\text { Firm FE } \\
N \\
\text { adj. } R^{2} \\
N \text { clusters }\end{array}$ & $\begin{array}{c}\text { Yes } \\
\text { No } \\
1,496,021 \\
0.211 \\
210\end{array}$ & $\begin{array}{c}\text { Yes } \\
\text { No } \\
1,496,021 \\
0.416 \\
210\end{array}$ & $\begin{array}{c}\text { Yes } \\
\text { No } \\
1,496,021 \\
0.666 \\
210\end{array}$ & $\begin{array}{c}\text { Yes } \\
\text { No } \\
1,496,021 \\
0.211 \\
210\end{array}$ & $\begin{array}{c}\text { Yes } \\
\text { No } \\
1,496,021 \\
0.416 \\
210\end{array}$ & $\begin{array}{c}\text { Yes } \\
\text { No } \\
1,496,021 \\
0.666 \\
210\end{array}$ \\
\hline \multicolumn{7}{|l|}{2007} \\
\hline $\begin{array}{l}\text { DPat }_{f p c} \\
\text { DProcess }_{f p} * \text { DPat }_{f p c}\end{array}$ & $\begin{array}{c}1.631^{* * *} \\
(0.088)\end{array}$ & $\begin{array}{c}1.462 * * * \\
(0.069)\end{array}$ & $\begin{array}{l}0.170^{* *} \\
(0.024)\end{array}$ & $\begin{array}{c}1.451^{* * *} \\
(0.084) \\
0.403^{* * *} \\
(0.033)\end{array}$ & $\begin{array}{c}1.266 * * * \\
(0.069) \\
0.437^{* * *} \\
(0.034)\end{array}$ & $\begin{array}{c}0.185^{* * *} \\
(0.021) \\
-0.035^{* * *} \\
(0.012)\end{array}$ \\
\hline \multicolumn{7}{|l|}{2011} \\
\hline $\begin{array}{l}\text { DPat }_{f p c} \\
\text { DProcess } f p_{f} * \text { DPat }_{f p c}\end{array}$ & $\begin{array}{c}1.587^{* * *} \\
(0.091)\end{array}$ & $\begin{array}{c}1.450^{* * * *} \\
(0.079)\end{array}$ & $\begin{array}{c}0.137^{* * *} \\
(0.021)\end{array}$ & $\begin{array}{c}1.456^{* * *} \\
(0.091) \\
0.273^{* * *} \\
(0.033)\end{array}$ & $\begin{array}{c}1.327^{* * *} \\
(0.078) \\
0.257^{* * *} \\
(0.036)\end{array}$ & $\begin{array}{c}0.129^{* * *} \\
(0.019) \\
0.016 \\
(0.013)\end{array}$ \\
\hline
\end{tabular}

Note. Table reports results of regressions at the firm-product-country level, using data on exports, quantity and unit value for years $2001,2007,2011$. Robust standard errors clustered at country level in parenthesis. ${ }^{*} p<0.10,{ }^{* *} p<0.05$, ${ }^{* * *} p<0.01$

Table 7: Across destinations, within firms-products: firm-country and firm-product-country dummy

\begin{tabular}{|c|c|c|c|c|c|c|}
\hline & $\begin{array}{c}(1) \\
\ln X_{f c p t}\end{array}$ & $\begin{array}{c}(2) \\
\ln \text { Quantity }_{\text {fcpt }}\end{array}$ & $\begin{array}{c}(3) \\
\ln \text { UnitValue }_{f c p t}\end{array}$ & $\begin{array}{c}(4) \\
\ln X_{f c p t}\end{array}$ & $\begin{array}{c}(5) \\
\ln \text { Quantity }_{f c p t}\end{array}$ & $\begin{array}{c}(6) \\
\ln \text { UnitValue }_{f c p t}\end{array}$ \\
\hline \multicolumn{7}{|l|}{2002} \\
\hline $\operatorname{DPat}_{f c}$ & $\begin{array}{c}0.496^{* * *} \\
(0.061)\end{array}$ & $\begin{array}{c}0.534^{* * * *} \\
(0.061)\end{array}$ & $\begin{array}{c}-0.038^{* * *} \\
(0.008)\end{array}$ & & & \\
\hline$D_{P a t} f p c$ & & & & $\begin{array}{c}0.739^{* * *} \\
(0.079)\end{array}$ & $\begin{array}{c}0.740^{* * *} \\
(0.079)\end{array}$ & $\begin{array}{l}-0.001 \\
(0.008)\end{array}$ \\
\hline Firm-Product FE & Yes & Yes & Yes & Yes & Yes & Yes \\
\hline Country FE & Yes & Yes & Yes & Yes & Yes & Yes \\
\hline$N$ & $1,197,529$ & $1,197,529$ & $1,197,529$ & $1,197,529$ & $1,197,529$ & $1,197,529$ \\
\hline adj. $R^{2}$ & 0.552 & 0.687 & 0.852 & 0.552 & 0.687 & 0.852 \\
\hline$N$ clusters & 228 & 228 & 228 & 228 & 228 & 228 \\
\hline \multicolumn{7}{|l|}{2007} \\
\hline $\operatorname{DPat}_{f c}$ & $\begin{array}{c}0.464^{* * *} \\
(0.048)\end{array}$ & $\begin{array}{c}0.487^{* * *} \\
(0.049)\end{array}$ & $\begin{array}{c}-0.023^{* *} \\
(0.009)\end{array}$ & & & \\
\hline$D_{P a t} f p c$ & & & & $\begin{array}{c}0.651^{* * *} \\
(0.063)\end{array}$ & $\begin{array}{c}0.664^{* * *} \\
(0.061)\end{array}$ & $\begin{array}{c}0.013 \\
(0.010)\end{array}$ \\
\hline \multicolumn{7}{|l|}{2011} \\
\hline $\operatorname{DPat}_{f c}$ & $\begin{array}{c}0.420^{* * *} \\
(0.045)\end{array}$ & $\begin{array}{c}0.432^{* * *} \\
(0.048)\end{array}$ & $\begin{array}{l}-0.012 \\
(0.011)\end{array}$ & & & \\
\hline$D_{P a t} f p c$ & & & & $\begin{array}{c}0.593^{* * *} \\
(0.059)\end{array}$ & $\begin{array}{c}0.591^{* * *} \\
(0.062)\end{array}$ & $\begin{array}{c}0.001 \\
(0.010)\end{array}$ \\
\hline
\end{tabular}

Note. Table reports results of regressions at the firm-product-country level, using data on exports, quantity and unit value for years $2001,2007,2011$. Robust standard errors clustered at country level in parenthesis. ${ }^{*} p<0.10,{ }^{* *}$ $p<0.05,{ }^{* * *} p<0.01$ 
with a quantity effect (i.e., firms export more instead of exporting at a higher unit value). The export premium is slightly larger when accounting for countryspecific patenting activity within a firm (i.e., comparing coefficients on $D P a t_{f c}$ and on $D P a t_{f}$ ). The same message emerges when considering the patent coverage at the product level in columns (4)-(6) of both tables: there is evidence of an export premium, and almost all the premium is associated with a quantity effect. The premium becomes very large: the value of transactions involving patent protection is at least three times larger across the various specifications, in the range of 315-374 percent. The increase in the estimated patent premium, when moving from the firm specification to the firm-product specification, suggests the existence of a patent-product effect that comes on top of the well-known firmlevel effect associated with a generic superior technological capability of the firm. When accounting for general firm fixed effects (see Appendix Table B1), the unitvalue premium associated with the variables $D P a t_{f c}$ and $D P a t_{f p c}$ disappears. This result indicates that the price premium is associated with a firm effect, which, in turn, is correlated with whether the firm has a patent or not. However, the quantity premium remains strong in this specification.

Table 6 extends the results presented in columns (4)-(6) of Table 5 by estimating a differentiated effect between patents protecting actual features of products and patents protecting their production process. In columns (1)-(3), we estimate the baseline specification on a sample that excludes firm-product-patent observations for which we are not able to categorize the associated patent into product versus process. In 2011, a total of 57,897 firm-product-patent observations among the 187,802 observations that we can categorize relate to a process (i.e., around 48\%). The regression results are very similar to the benchmark estimates presented in columns (4)-(6) of Table 5, suggesting that missing observations do not bias the results. In the last three columns, we interact the independent variable $D P a t_{f p c}$ with the dummy variable PProcess $_{f p}$. Thus, the interaction term takes value 1 if the product is protected by a process patent and 0 otherwise. The results suggest that products covered by a new production process enjoy a higher quantity premium and are sold at a more competitive price. This evidence is consistent with the view that process innovation might decrease the production costs. However, the results on price premium appear somewhat fragile.

\section{Country-level heterogeneity}

The next set of regressions, presented in Table 7, are more demanding. They control for firm-product fixed effects as well as country fixed effects. One can interpret the estimates as capturing the extent to which patent protection in country $c$ by firm $f$ (and for product $p$ in columns (4)-(6)) is associated with higher export values for product $p$ in that country, compared to the average export value for the same firm and product but in other destinations not covered by a patent. ${ }^{15}$ This is our country level source of heterogeneity. Results confirm the existence of an export premium that is mainly driven by a quantity effect.

\footnotetext{
${ }_{15}$ Notice that the inclusion of these fixed effects does not allow us to use $\operatorname{DPat}_{f}$ and $\operatorname{DPat}_{f p}$.
} 
Table 8: Exports and firm-product-country patents, 2002-2011

\begin{tabular}{|c|c|c|c|c|c|c|}
\hline & $\begin{array}{c}(1) \\
\ln \stackrel{X}{f c p t}\end{array}$ & $\begin{array}{c}(2) \\
\ln Q_{\text {Quntity }} \\
\text { fcpt }\end{array}$ & $\begin{array}{c}(3) \\
\ln \text { UnitValue }_{f c p t}\end{array}$ & $\begin{array}{c}(4) \\
\ln \stackrel{(}{X}_{f c p t}\end{array}$ & $\begin{array}{c}(5) \\
\ln \text { Quantity }_{f c p t}\end{array}$ & $\begin{array}{c}(6) \\
\ln \text { UnitValue }_{f c p t}\end{array}$ \\
\hline \multicolumn{7}{|l|}{ ALL FIRMS } \\
\hline$D_{P a t} f p c$ & $\begin{array}{c}0.099^{* * * *} \\
(0.008)\end{array}$ & $\begin{array}{c}0.111^{* * *} \\
(0.008)\end{array}$ & $\begin{array}{c}-0.012^{* * *} \\
(0.003)\end{array}$ & $\begin{array}{c}0.096^{* * *} \\
(0.008)\end{array}$ & $\begin{array}{c}0.106^{* * *} \\
(0.008)\end{array}$ & $\begin{array}{c}-0.010^{* * *} \\
(0.003)\end{array}$ \\
\hline $\begin{array}{l}N \\
\text { adj. } R^{2} \\
N \text { clusters }\end{array}$ & $\begin{array}{c}12,864,898 \\
0.790 \\
2178\end{array}$ & $\begin{array}{c}12,864,898 \\
0.835 \\
2178\end{array}$ & $\begin{array}{c}12,864,898 \\
0.878 \\
2178\end{array}$ & $\begin{array}{c}12,110,678 \\
0.788 \\
2070\end{array}$ & $\begin{array}{c}12,110,678 \\
0.832 \\
2070\end{array}$ & $\begin{array}{c}12,110,678 \\
0.877 \\
2070\end{array}$ \\
\hline \multicolumn{7}{|l|}{ ONLY PATENTING FIRMS } \\
\hline DPat $_{f p c}$ & $\begin{array}{c}0.090^{* * * *} \\
(0.007)\end{array}$ & $\begin{array}{c}0.098^{* * * *} \\
(0.007)\end{array}$ & $\begin{array}{c}-0.007^{* * *} \\
(0.003) \\
\end{array}$ & $\begin{array}{c}0.090^{* * *} \\
(0.008)\end{array}$ & $\begin{array}{c}0.102^{* * *} \\
(0.008)\end{array}$ & $\begin{array}{c}-0.012^{* * *} \\
(0.003)\end{array}$ \\
\hline $\begin{array}{l}N \\
\text { adj. } R^{2} \\
N \text { clusters }\end{array}$ & $\begin{array}{c}3,427,558 \\
0.799 \\
2107\end{array}$ & $\begin{array}{c}3,427,558 \\
0.831 \\
2107\end{array}$ & $\begin{array}{c}3,427,558 \\
0.860 \\
2107\end{array}$ & $\begin{array}{c}2,849,061 \\
0.792 \\
1886\end{array}$ & $\begin{array}{c}2,849,061 \\
0.817 \\
1886\end{array}$ & $\begin{array}{c}2,849,061 \\
0.842 \\
1886\end{array}$ \\
\hline \multicolumn{7}{|c|}{ ONLY PATENTING FIRMS - NON-SWITCHERS + SWITCHERS FROM 0 TO 1} \\
\hline DPat $_{f p c}$ & $\begin{array}{c}0.094^{* * * *} \\
(0.007) \\
\end{array}$ & $\begin{array}{c}0.094^{* * * *} \\
(0.007) \\
\end{array}$ & $\begin{array}{c}0.000 \\
(0.004) \\
\end{array}$ & $\begin{array}{c}0.088^{* * *} \\
(0.008) \\
\end{array}$ & $\begin{array}{c}0.098^{* * *} \\
(0.009) \\
\end{array}$ & $\begin{array}{c}-0.010^{* *} \\
(0.004) \\
\end{array}$ \\
\hline $\begin{array}{l}N \\
\text { adj. } R^{2} \\
N \text { clusters }\end{array}$ & $\begin{array}{c}3,263,442 \\
0.798 \\
2107 \\
\end{array}$ & $\begin{array}{c}3,263,442 \\
0.829 \\
2107 \\
\end{array}$ & $\begin{array}{c}3,263,442 \\
0.858 \\
2107 \\
\end{array}$ & $\begin{array}{c}2,685,154 \\
0.790 \\
1886 \\
\end{array}$ & $\begin{array}{c}2,685,154 \\
0.813 \\
1886 \\
\end{array}$ & $\begin{array}{c}2,685,154 \\
0.839 \\
1886 \\
\end{array}$ \\
\hline \multicolumn{7}{|c|}{ ONLY PATENTING FIRMS - NON-SWITCHERS + SWITCHERS FROM 1 TO 0} \\
\hline$D_{P a t} f p$ & $\begin{array}{c}0.098 * * * \\
(0.007) \\
\end{array}$ & $\begin{array}{c}0.121^{* * * *} \\
(0.008) \\
\end{array}$ & $\begin{array}{c}-0.023^{* * * *} \\
(0.004) \\
\end{array}$ & $\begin{array}{c}0.115^{* * * *} \\
(0.009) \\
\end{array}$ & $\begin{array}{c}0.128^{* * *} \\
(0.010) \\
\end{array}$ & $\begin{array}{r}-0.013^{*} \\
(0.005) \\
\end{array}$ \\
\hline $\begin{array}{l}N \\
\text { adj. } R^{2} \\
N \text { clusters }\end{array}$ & $\begin{array}{c}3,112,750 \\
0.797 \\
2107 \\
\end{array}$ & $\begin{array}{c}3,112,750 \\
0.829 \\
2107 \\
\end{array}$ & $\begin{array}{c}3,112,750 \\
0.859 \\
2107 \\
\end{array}$ & $\begin{array}{c}2,538,130 \\
0.789 \\
1886 \\
\end{array}$ & $\begin{array}{c}2,538,130 \\
0.813 \\
1886 \\
\end{array}$ & $\begin{array}{c}2,538,130 \\
0.839 \\
1886 \\
\end{array}$ \\
\hline $\begin{array}{l}\text { Firm-Product-Country FE } \\
\text { Country-Year FE } \\
\text { Product-Country-Year FE }\end{array}$ & $\begin{array}{l}\text { Yes } \\
\text { Yes } \\
\text { No }\end{array}$ & $\begin{array}{l}\text { Yes } \\
\text { Yes } \\
\text { No }\end{array}$ & $\begin{array}{l}\text { Yes } \\
\text { Yes } \\
\text { No }\end{array}$ & $\begin{array}{l}\text { Yes } \\
\text { No } \\
\text { Yes }\end{array}$ & $\begin{array}{l}\text { Yes } \\
\text { No } \\
\text { Yes }\end{array}$ & $\begin{array}{l}\text { Yes } \\
\text { No } \\
\text { Yes }\end{array}$ \\
\hline
\end{tabular}

Interestingly, similarly to the results presented in Table 5, accounting for firmproduct specific patents increases the associated coefficient. Overall, the results suggest an export premium in the range of 52-109 percent.

We have also estimated the regression models in Table 7, columns (4)-(6), on three different sub-samples to assess the sensitivity of the findings to sample composition (not reported). We have kept only countries with at least one positive 10-year stock of patents for at least one firm (68 countries in 2011), we have kept only OECD countries, and we have kept only products with at least one positive stock for at least one firm. Results are qualitatively similar; although the export premium is slightly lower. It is in the range of 31-66 percent.

\subsection{Before and after effects}

The previous analyses have shown that, within a country-product pair, patenting firms enjoy an export premium that is mainly driven by a quantity effect. The premium becomes larger when we focus on patents protecting exports to a given firm-product-country transaction. Although the previous analyses have the advantage of using information on all firm-product-country observations related to 
a patent, they neglect effects that are specific to the firm-product-country flow. For example, a firm can export more expensive varieties (within an HS6 product category) to richer countries (Manova and Zhang, 2012); these effects, in turn, may be correlated to the decision to apply for a patent in that country.

In this section, we account for firm-product-country effects. Exploiting the time dimension, we estimate the following equation:

$$
\ln Y_{f p c t}=a+\beta D P a t_{f p c}+\theta_{f p c}+\theta_{c t}+\varepsilon_{f p c t}
$$

where $\ln Y_{\text {fpct }}$ denotes, the logarithm of, alternatively, the total value, quantity and unit value of the firm's exports in the country-product pair, DPat ${ }_{f p c}$ is a binary variable taking value of 1 if the firm-product-country flow is matched to a stock of patent, $\theta_{f p c}$ are a set of firm-product-country fixed effects and $\theta_{c t}$ destination-year fixed effects. It is crucial to note that the presence of $\theta_{f p c}$ makes the identification of $\beta$ depending solely on the 'switchers,' i.e., firm-productcountries flows that either switch from 0 to 1 (starting to patent) or from 1 to 0 (meaning that they do not have any patent in the previous 10 years). In this quasi difference in difference estimation, the set of destination-year fixed effects $\left(\theta_{c t}\right)$ account for destination specific time varying characteristics that are common to both groups (switchers and non-switchers). These includes 'gravity' variables such as the country GDP per capita, the cyclical component of the demand in the destination country, and shocks and systemic changes. For instance, Coelli et al. (2016) show that most favored nation (MFN) tariff cuts in the aftermath of the Uruguay Round in 1994 had a large effect on firm-level innovation by improving market access. Similarly, Aghion et al. (2018) show that French firms respond to demand shocks in their export destinations by patenting more. Our set of destination-year fixed effects account for all these effects.

Results from estimation of equation (5) are reported in Table 8, columns (1)-(3). In the first panel, we use the whole sample of trade flows. The sample includes the 'switchers' (459,780 observations) and all other observations, which fall in the following cases: (i) observations by firms that never patented; (ii) observations by firms that patented in another product-country variety; (iii) observations by firms that do have a positive patent stock in the relevant productcountry throughout the whole observation period. Within firm-product-country flows, a switch in patenting status is associated with an average increase in export value of 10 percent. As in the cross-sectional analysis, it is apparent that such an increase is mostly associated with a quantity effect: the coefficient on unit value is negative and significant with a very low magnitude (-0.012). Columns (4)-(6) report the results from an alternative specification that controls for country-product-year fixed effects instead of simply country-year effects. This specification accounts for shocks that are specific to a given product category, and leads to very similar results.

A potential concern related to the results of the first panel of Table 8 is that the country-year and country-product-year fixed effects exploit information from transactions by all firms. However, it might be that patenting and non-patenting firms are so different that they are not even competing in the same productdestination markets. Hence, in order to enhance the comparability between both 
Table 9: Exports and firm-product-country patents: accounting for firm-products time-varying effects

\begin{tabular}{|c|c|c|c|c|c|c|}
\hline & $\begin{array}{c}(1) \\
\ln X_{f c p t}\end{array}$ & $\begin{array}{c}(2) \\
\ln Q_{\text {uantity }}{ }_{f c p t}\end{array}$ & $\begin{array}{c}(3) \\
\ln \text { UnitValue }_{f c p t}\end{array}$ & $\begin{array}{c}(4) \\
\ln X_{f c p t}\end{array}$ & $\begin{array}{c}(5) \\
\ln \text { Quantity }_{f c p t}\end{array}$ & $\begin{array}{c}(6) \\
\ln \text { UnitValue }_{f c p t}\end{array}$ \\
\hline \multicolumn{7}{|l|}{ ONLY PATENTING FIRMS } \\
\hline $\operatorname{DPat}_{f p c}$ & $\begin{array}{c}0.063^{* * * *} \\
(0.011)\end{array}$ & $\begin{array}{c}0.057^{* * * *} \\
(0.012)\end{array}$ & $\begin{array}{c}0.006 \\
(0.005)\end{array}$ & $\begin{array}{c}0.064^{* * *} \\
(0.013)\end{array}$ & $\begin{array}{c}0.058^{* * * *} \\
(0.014)\end{array}$ & $\begin{array}{c}0.006 \\
(0.006)\end{array}$ \\
\hline$N$ & $3,122,592$ & $3,122,592$ & $3,122,592$ & $2,540,788$ & $2,540,788$ & $2,540,788$ \\
\hline adj. $R^{2}$ & 0.839 & 0.863 & 0.886 & 0.834 & 0.851 & 0.867 \\
\hline$N$ clusters & 2106 & 2106 & 2106 & 1886 & 1886 & 1886 \\
\hline Firm-Product-Country FE & Yes & Yes & Yes & Yes & Yes & Yes \\
\hline Firm-Product-Year FE & Yes & Yes & Yes & Yes & Yes & Yes \\
\hline Country-Year FE & Yes & Yes & Yes & No & No & No \\
\hline Product-Country-Year FE & No & No & No & Yes & Yes & Yes \\
\hline
\end{tabular}

Note. Table reports results of estimation from Equation 6 at the firm-product-country level, using data on exports, quantity and unit value for years 2002-2011. Robust standard errors clustered at destination-year level in parenthesis. ${ }^{*} p<0.10,^{* *}$ $p<0.05,{ }^{* * *} p<0.01$

groups, we estimate equation (5) using only the subset of patenting firms. Thus, we exclude observations of type (i) as described above. Results, presented in the second panel of Table 8, show that coefficients are very similar to the ones obtained before, with the effect on export value around 9 percent.

Finally, in the third and the fourth panel of Table 8, we check whether a specific group of switchers drives the results. Among patenting firms, the total number of 'switchers,' that is firm-product-country cells that exhibit a change in the variable $D P a t_{f p c}$ in the study period, reaches 459,780 . Of those, around 60 percent have a 'first export, then patent' dynamics, with a unique switching pattern in $D P a t_{f p c}$, i.e., from 0 to 1 . On the other hand, around 40 percent of observations have a 'first patent, then export' dynamics, ${ }^{16}$ with two possible switching patterns: from 1 to 0 (around 90\%) and from 1 to 0 , followed by 0 to 1 (around 10\%). In the third panel of Table 8, we restrict the set of switchers to the type 'first export, then patent' (i.e., from 0 to 1 ). In the fourth panel, we restrict the set of switchers to the type 'first patent, then export,' excluding multiple switchers. ${ }^{17}$ In both exercises, the composition of the remaining sample is the same as in the second panel and includes cases (ii) and (iii) discussed above. Results remain very similar to those previously obtained, with coefficients on the export value in the range of $0.088-0.115$ - suggesting that the positive effect is not driven by a particular category of 'switchers.'

16 The analysis on the exporting and patenting dynamics that we present here resonates with the evidence presented in Section 2.3. Note, however, that the two are based on very different sets of observations. We recall the most relevant differences. First, here we are employing repeated observations over time in a given firm-product-country triplet, while in Section 2.3 we were only using the unique occurrence of a given triplet. Second, as we have data on a transaction only when trade occurs, this implies an over-representation of the 'first export, then patent' occurrences, which by construction are always switchers (from 0 to 1 ). On the other hand, the 'first patent, then export' occurrences are switchers only when they go from 1 to 0 ; all other cases are within group (iii). While the first explanation is responsible for the sharp increase in the number of available observations (from 118,365 in Section 2.3 to $459,780)$; the second is related to the change in the proportion of the switches.

${ }^{17}$ Notice that this classification includes years 2002 and 2003, so an exporter that starts in 2002 with a patent is classified as a 'first patent, then export.' 
Regression equation (5) contains a rich set of fixed effects that should insulate our results from endogeneity concerns related to time-invariant unobserved characteristics of firm-product-countries susceptible to affect both the patent propensity and the export performance. In order to account also for some timevarying unobserved effects, we estimate the following specification:

$$
\ln Y_{f p c t}=a+\beta D P a t_{f p c}+\theta_{f p c}+\theta_{c t}+\theta_{f p t}+\varepsilon_{f p c t}
$$

Equation (6) augments equation (5) with the set of fixed effects, $\theta_{f p t}$, which capture time-varying characteristics that are specific to the firm and to the firmproduct. For example, managerial capabilities may change in time and may affect both the propensity to innovate/patent of the firm (and of the firm-product) and the expansion on international markets. This specification achieves identification through changes in patenting status of a given firm-product in a subset of its destination markets. For instance, a firm exporting a given category of motorvehicles to three different markets, may decide to apply for a patent only in two destinations. In this case, the effect is identified from a differential performance over time after the application. Indeed, equation (6) exploits information from firms that export the same HS6 product variety to several destinations but that have filed for the related patent only in some of the destination countries. This specification allows us to isolate a 'patent protection effect,' which is specific to the countries in which the firm has filed for patent, from a more general 'innovation effect,' which is embedded in the exported product, irrespective of the patent protection in the destination market. Table 9 presents the results. Despite the more demanding specification, the qualitative results remain unchanged. The coefficient associated with the patent dummy variable in the export value equation is positive and significant, due to the quantity effect. The magnitude is reduced by around one third with respect to Table 8, panel two. As explained above, this reduction can be related to capturing only the 'patent protection effect.'

\subsection{Sectoral heterogeneity}

So far, for the sake of generality, we have abstracted away from sectoral heterogeneity. However, it is well known that different sectors display diverse propensity to patent, see also Table 2. We investigate this aspect in Table 10 using $\mathrm{DPat}_{f p c}$ as independent variable. Due to the low number of patents in some sectors, disaggregated estimates can be noisy, especially in our high-dimensional fixed effect framework. In order to enhance the stability and the accuracy of estimation we use the panel with the entire sample of firms and report results from a specification with firm-product and country-year fixed effects (columns 1-3), and with firm-product-country and country-year fixed effects (columns 4-6), as in columns (1)-(3), Table 8.

Overall, sectoral patterns are rather similar to what we observe in the aggregate: patent premia are mostly associated with a quantity effect, and are in the range of 11-14 percent when accounting for firm-product-country effects (columns 4-6), with the exception of the medium-low-tech sector, where it is around 2 percent. There is a positive price premium in the pharmaceutical sec- 
Table 10: Exports and firm-product-country patents, by sectors, 2002-2011

\begin{tabular}{lcccccc}
\hline & $(1)$ & $(2)$ & $(3)$ & $(4)$ & $(5)$ & $(6)$ \\
& $\ln X_{f c p t}$ & $\ln Q u a_{f c p t}$ & $\ln U V_{f c p t}$ & $\ln X_{f c p t}$ & $\ln Q u a_{f c p t}$ & $\ln U V_{f c p t}$ \\
\hline High-tech & $0.522^{* * *}$ & $0.559^{* * *}$ & $-0.037^{* * *}$ & $0.122^{* * *}$ & $0.142^{* * *}$ & $-0.020^{* * *}$ \\
& $(0.016)$ & $(0.017)$ & $(0.006)$ & $(0.012)$ & $(0.014)$ & $(0.008)$ \\
Medium-high-tech & $0.687^{* * *}$ & $0.708^{* * *}$ & $-0.021^{* * *}$ & $0.110^{* * *}$ & $0.123^{* * *}$ & $-0.014^{* * *}$ \\
& $(0.019)$ & $(0.019)$ & $(0.004)$ & $(0.012)$ & $(0.012)$ & $(0.005)$ \\
Medium-low-tech & $0.485^{* * *}$ & $0.486^{* * *}$ & -0.001 & $0.023^{*}$ & $0.022^{*}$ & 0.001 \\
& $(0.016)$ & $(0.016)$ & $(0.006)$ & $(0.013)$ & $(0.013)$ & $(0.006)$ \\
Low-tech & $0.502^{* * *}$ & $0.478^{* * *}$ & $0.025^{* * *}$ & $0.124^{* * *}$ & $0.134^{* * *}$ & -0.010 \\
& $(0.017)$ & $(0.017)$ & $(0.005)$ & $(0.014)$ & $(0.014)$ & $(0.006)$ \\
Pharmaceutical Products & $0.311^{* * *}$ & $0.280^{* * *}$ & $0.031^{*}$ & $0.132^{* * *}$ & $0.104^{* *}$ & 0.028 \\
& $(0.029)$ & $(0.031)$ & $(0.016)$ & $(0.044)$ & $(0.046)$ & $(0.025)$ \\
\hline
\end{tabular}

Note. Table reports results of regressions at the firm-product-country level, using data on exports, quantity and unit value for years 2002-2011, by sectors. Columns 1-3 report the coefficient on DPat $_{f p c}$ with Firm-Product, and Country-Year fixed effects. Columns 4-6 employ Firm-ProductCountry and Country-Year fixed effects. Robust standard errors clustered at country-year level in parenthesis. ${ }^{*} p<0.10,{ }^{* *} p<0.05,{ }^{* * *} p<0.01$

(a) With country-year fixed effects

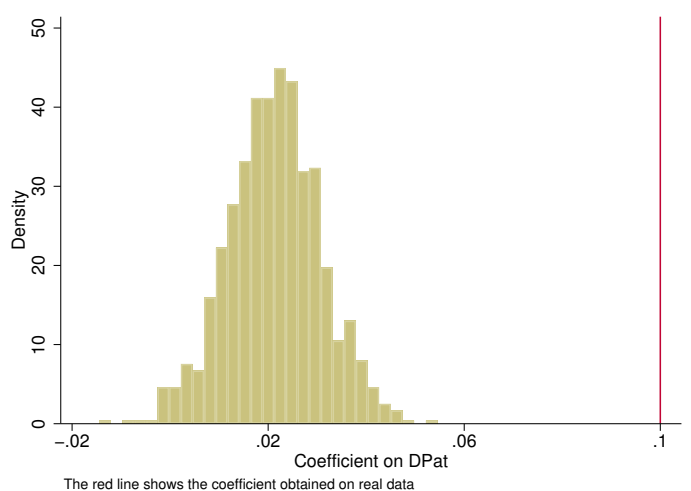

(b) With country-product-year fixed effects

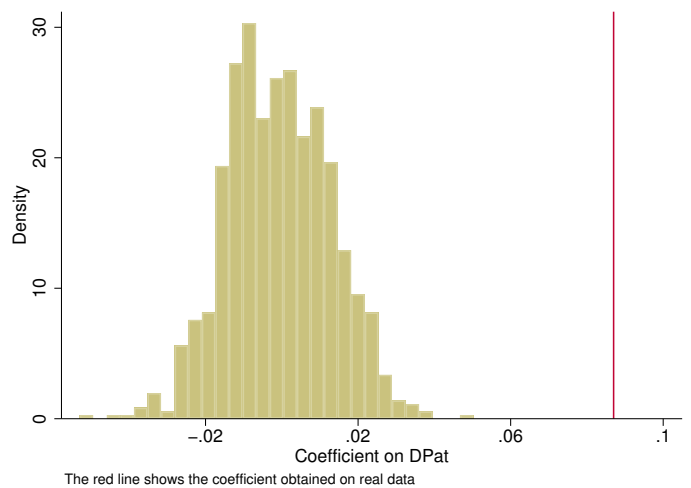

Figure 3: Distribution of coefficients on $D P a t_{f p c}$ in the export value estimation of Equation 5 on simulated data

tor, around 3 percent, even if the coefficient is significant at 10-percent confidence level only in the first specification. Interestingly, this estimate is quite close to the average price increase experienced by a patented molecule as in Duggan et al. (2016). Quite surprisingly, there is a positive price effect also in the low-tech sector. One should be cautious, however, in interpreting this last result. Because of the very low patent intensity of these sectors (see Table 2), the results are driven by very few observations.

\section{$5 \quad$ Placebo analysis and additional results}

Equation (5) controls for common average trends between switchers and nonswitchers using a full set of country-year and country-product-year fixed effects. 
However, all observations may not all be equally well represented by such a common average. In particular, there could be some non-switching firm-productcountries trade flows with a dynamics similar to the switchers. If this were case, there could be some underlying factor other than the patenting activity that affects the dynamics of the switchers and non-switchers.

In order to check that our results are not driven by such factors, we run a test in the spirit of placebo analysis (Athey and Imbens, 2017). We first select, among all observations, the ones we observe for all ten years. This allows us to compare switching and non-switching observations abstracting from possible differences in the observation period. Such a choice leaves us with 1,895,930 observations. To check that the results of the placebo are not driven by this particular cut of the data, we estimate equation (5) on the (log) export value both with countryyear and with country-product-year fixed effects. Coefficients (clustered standard errors) on DPat $_{f p c}$ are respectively 0.100 (0.008) and 0.087 (0.009), which is in line with the results presented in Table 8 . We then exclude observations that are matched to a patent (around 18\%), and randomly reassign their different sequences of ' 0 ' and ' 1 ' to the other firm-product-country transactions, keeping constant the share of switchers within products-country pairs. After each random assignment, we estimate equation (5) on the resulting sample, both with countryyear and with country-product-year fixed effects.

After 1,000 simulations, we obtain a distribution of coefficients on $D P a t_{f p c}$ which is reported in Figure 3. Panel (a) controls for country-year fixed effects and Panel (b) controls for country-product-year fixed effects. The vertical lines indicate the value of the coefficient obtained using real data. In panel (a), the average estimated coefficient after 1,000 simulations is 0.021 (and standard deviation 0.009), quite far from the 0.100 coefficient we obtain on real data. In panel (b), which controls for common product-country-year fixed effects, there is again a sizeable difference of around 0.8 between the average coefficient, 0 (and standard deviation 0.014), and the real coefficient, 0.087. Both results are reassuring. In particular, the fact that the impact of patenting is on average 0 when we randomly assign treatment and control with country-products-year fixed effects makes us confident that, within a product-country pair, trade flows do have quite homogeneous dynamics, and this in turn makes it more likely that what happens after a real patent event is a genuine effect of the patent.

\subsection{Accounting for selection in exporting}

Selection in exporting is another source of bias that can affect our results. A nonpatenting firm that exports a given product to a given destination may have an above-average export performance due to some unobserved characteristics. This suggests that our estimates are conservative with respect to selection. Our beforeand-after analysis already accounts for cross-sectional dimensions of selection bias usually investigated in the trade literature (Crozet et al., 2011). In this section, we investigate to what extent the results could be affected by selection in the panel dimension.

Our approach is the following. First, we expand our dataset at the firmproduct-country level, to include zeros when a trade flow is not observed. Since 
Table 11: Exports and firm-product-country patents: extensive and intensive margins

\begin{tabular}{lccc}
\hline & $(1)$ & $(2)$ & $(3)$ \\
Dep. variable & $D_{\text {exp }}$ & $\ln X_{f c p t}$ & $X_{f c p t}$ \\
\hline DPat $_{f p c}$ & $0.007^{* * *}$ & $0.085^{* * *}$ & $0.234^{* * *}$ \\
& $(0.000)$ & $(0.007)$ & $(0.031)$ \\
\hline$N$ & $23,895,179$ & $1,516,737$ & $23,895,179$ \\
adj. $R^{2}$ & 0.584 & 0.792 & \\
Pseudo $R^{2}$ & & & 0.924 \\
$N$ clusters & 770 & 757 & 757 \\
Firm-Product-Country FE & Yes & Yes & Yes \\
Country-Year FE & Yes & Yes & Yes \\
\hline
\end{tabular}

Note. The table reports results of a selection equation with binary dependent variable (column 1), and of export value equation with log export value (column 2), estimated via high-dimensional fixed effects, and export values with zeros (column 3), estimated via pseudo-poisson. Robust standard errors clustered at destinationyear level in parenthesis. ${ }^{*} p<0.10,{ }^{* *} p<0.05,{ }^{* * *} p<0.01$

we do not have information on firms' domestic production, we place zeros on a given firm-product-country triplet if the same firm-product variety is observed in another country. Practically, we take the initial and the final year in which we observe a firm-product variety, and we place zeros in the empty years, in which the variety is not observed - thereby eliminating gaps in the series - as well as in all countries to which the variety is not exported. In order to enhance the computational feasibility of the exercise, we restrict the dataset to firms, products and countries that have at least one patent matched during the period. Given our 'within' identification, this restriction will not affect the estimates. Using this expanded dataset, which contains around 25,000,000 observations, we first estimate the effect of a switch in the patenting status on the probability to export. Then, using the approach suggested by Silva and Tenreyro (2006), we estimate an export equation in levels with the zeros via the pseudo-maximumlikelihood poisson technique. ${ }^{18}$ Notice that this approach does not allow us to decompose the quantity and price effect.

Results are reported in Table (11). Column (1) reports the result of the selection equation in which the dependent variable is a binary variable denoting whether a firm is exporting in the given product-country. Because of the numerous fixed effects, we estimate the equation via a simple linear probability model. Results suggest a positive and significant association between patents and the probability to export at the firm-product-country level. The coefficient reaches 0.7 percentage point, which is is non-negligible compared to the unconditional probability to export in any given product-country of 6 percent.

Column (2) reports the standard estimation of equation (5) on log export

$\overline{18}$ We have used the Stata command $p p m l h d f e$, which allows to include multi-way fixed effects. 
value. The coefficient on $D P a t_{f p c}$ is equal to 0.085 , only slightly different from the 0.090 coefficient in Table 8, second panel. ${ }^{19}$. Finally, column (3) reports the results of the estimation of the equation on export value in levels, and with zeros. The estimated coefficient suggests that a change in $D P a t_{f p c}$ is associated with an increase in export value of around 26 percent, confirming that our previous estimates are conservative with respect to the selection issue.

\section{Concluding remarks}

This paper reports new evidence on the extent to which international trade hinges on patents. It analyzes export and patenting activities of a panel of French exporting firms in the period from 2002 to 2011. The noticeable feature of our study is that we observe the patenting activity worldwide, which allows us to explore the extent to which patenting in a given country is associated with export in that destination. We are also able to match patents at the level of product categories, which allows us to control for various sources of unobserved heterogeneity. The results of the empirical analysis provide an unprecedented perspective on the patenting and exporting behaviour of firms.

First, there is overwhelming evidence suggesting that patenting activity precedes exporting in a given product-country destination. This finding is not surprising but it establishes the validity of our empirical setup. By law, offering a product for sale counts as a 'public disclosure' of the invention-and inventions that are disclosed to the public cannot be patented. Therefore, inventions relating to products should first be submitted to the patent office before the product is commercialized. ${ }^{20}$

Second, we have exploited several sources of cross-sectional heterogeneity to identify the effect of patenting on total export value, as well as on the quantity and unit value of firm-product-country transactions. The evidence robustly suggests that export transactions display a much higher export value when they are covered by a patent. The patent premium is always larger than 30 percent across specifications and samples. Quite interestingly, the premium is almost completely explained by a quantity effect. Unit values on transactions covered by patents are higher only in some selected sectors, most notably, pharmaceuticals.

Third, exploiting the longitudinal dimension of the data we can also assess the effect of a patent filing on a continuing export transaction. Over time, patenting is associated with an increase in the value of exports of around 10 percent and again this is mainly due to a quantity effect. The richness of the dataset also enables us to identify a 'patent protection effect,' which is specific to the countries in which the firm has filed for patent, from a more general 'innovation effect,' which is embedded in the product-variety that is benefiting from the innovation, irrespective of where the product receives patent protection. These findings are robust to a series of alternative specifications and to a placebo test.

\footnotetext{
${ }^{19}$ The small difference is due to the different composition of the dataset, which in this case reduces the observations also with respect to products and countries. This in turn may affect the estimation of the product-country-year common trend

${ }^{20}$ Up to a one year 'grace period,' see 35 U.S. Code $\$ 102$, "Conditions for patentability; novelty."
} 
Taken together the results point to the existence of a relevant patent premium on the export values for transactions associated with patent protection. The very limited evidence of a positive premium on unit values, our proxy for price, poses some challenges to both future empirical and theoretical analysis. Large-scale empirical works matching together product-varieties, or even actual products, to patents are needed to confirm the findings of the present work. Currently, since we work at the product class level, we cannot exclude the possibility that the introduction of patented products with a higher price (e.g., a new mobile phone) is compensated by a decline in the price of the pre-existing phones in the same product category, with an average effect of zero. On a more theoretical viewpoint, our results suggest to explore models in which a substantial part of the value residing in foreign patent protection is in the legal security that it offers, rather than in the possibility to set monopoly prices.

\section{References}

Aghion, P., A. Bergeaud, M. Lequien, And M. J. Melitz (2018): "The Impact of Exports on Innovation: Theory and Evidence," Working Paper 24600, National Bureau of Economic Research.

Amable, B. And B. Verspagen (1995): "The role of technology in market shares dynamics," Applied Economics, 27, 197-204.

Amendola, G., G. Dosi, And E. Papagni (1993): "The dynamics of international competitiveness," Review of World Economics (Weltwirtschaftliches Archiv), 129, 451-471.

Arora, A., M. Ceccagnoli, And W. Cohen (2008): "R\&D and the patent premium," International Journal of Industrial Organization, 26, 1153-1179.

Athey, S. And G. W. Imbens (2017): "The state of applied econometrics: Causality and policy evaluation," Journal of Economic Perspectives, 31, 3-32.

Bernard, A. B., J. B. Jensen, S. J. Redding, And P. K. Schott (2007a): "Firms in International Trade," Journal of Economic Perspectives, 21, 105130.

Bernard, A. B., S. J. Redding, And P. K. Schott (2007b): "Comparative Advantage and Heterogeneous Firms," The Review of Economic Studies, 74, $31-66$.

Carlin, W., A. Glyn, And J. Van Reenen (2001): "Export Market Performance of OECD Countries: An Empirical Examination of the Role of Cost Competitiveness," Economic Journal, 111, 128-62.

Cassiman, B., E. Golovko, and E. Martínez-Ros (2010): "Innovation, exports and productivity," International Journal of Industrial Organization, $28,372-376$. 
Castellani, D. And A. Zanfei (2007): "Internationalisation, innovation and productivity: how do firms differ in Italy?" The World Economy, 30, 156-176.

Coelli, F., A. Moxnes, And K. H. Ulltveit-Moe (2016): "Better, faster, stronger: Global innovation and trade liberalization," Tech. rep., National Bureau of Economic Research.

Cohen, W. M., R. R. Nelson, And J. P. Walsh (2000a): "Protecting their intellectual assets: Appropriability conditions and why US manufacturing firms patent (or not)," Tech. rep., National Bureau of Economic Research Working Paper 7552.

(2000b): "Protecting Their Intellectual Assets: Appropriability Conditions and Why U.S. Manufacturing Firms Patent (or Not)," Working Paper 7552, National Bureau of Economic Research.

Correia, S. (2017): "Linear models with high-dimensional fixed effects: An efficient and feasible estimator," Technical report.

Crozet, M., K. Head, And T. Mayer (2011): "Quality sorting and trade: Firm-level evidence for French wine," The Review of Economic Studies, 79, 609-644.

De Rassenfosse, G., H. Dernis, and G. Boedt (2014): "An introduction to the Patstat database with example queries," Australian Economic Review, 47, 395-408.

De Rassenfosse, G. And A. B. Jaffe (2018): "Are patent fees effective at weeding out low-quality patents?" Journal of Economics \& Management Strategy, 27, 134-148.

Dosi, G., M. Grazzi, And D. Moschella (2015): "Technology and costs in international competitiveness: from countries and sectors to firms," Research Policy, 44, 1795-1814.

(2017): "What do firms know? What do they produce? A new look at the relationship between patenting profiles and patterns of product diversification," Small Business Economics, 48, 413-429.

Dosi, G., L. Marengo, and C. Pasquali (2006): "How much should society fuel the greed of innovators?: On the relations between appropriability, opportunities and rates of innovation," Research Policy, 35, 1110-1121.

Dosi, G., K. PavitT, And L. Soete (1990): The Economics of Technical Change and International Trade, New York: New York University Press.

Duggan, M., C. Garthwaite, And A. Goyal (2016): "The market impacts of pharmaceutical product patents in developing countries: Evidence from India," American Economic Review, 106, 99-135. 
FAGERBERG, J. (1988): "International competitiveness," The Economic Journal, $98,355-374$.

Ganglmair, B., W. Robinson, And S. M (2020): "Four Decades of Patent Claim Drafting: New Data and Stylized Facts," Tech. rep., In preparation.

Gould, D. M. And W. C. Gruben (1996): "The role of intellectual property rights in economic growth," Journal of Development Economics, 48, 323-350.

Guellec, D. And B. van Pottelsberghe (2000): "Applications, grants and the value of patent," Economics letters, 69, 109-114.

Hall, B., C. Helmers, M. Rogers, and V. Sena (2014): "The Choice between Formal and Informal Intellectual Property: A Review," Journal of Economic Literature, 52, 375-423.

Harhoff, D., F. M. Scherer, And K. Vopel (2003): "Citations, family size, opposition and the value of patent rights," Research policy, 32, 1343-1363.

Hu, A. AND I. PNG (2013): "Patent rights and economic growth: evidence from cross-country panels of manufacturing industries," Oxford Economic Papers, 65, 675-698.

Ivus, O. (2010): "Do stronger patent rights raise high-tech exports to the developing world?" Journal of International Economics, 81, 38 - 47.

Landesmann, M. And M. Pfaffermayr (1997): "Technological competition and trade performance," Applied Economics, 29, 179-196.

Laursen, K. And V. Meliciani (2010): "The role of ICT knowledge flows for international market share dynamics," Research Policy, 39, 687-697.

Lin, J. X. AND W. F. LinCOLn (2017): "Pirate's treasure," Journal of International Economics, 109, 235-245.

LyBbert, T. J. And N. J. Zolas (2014): "Getting patents and economic data to speak to each other: An 'Algorithmic Links with Probabilities' approach for joint analyses of patenting and economic activity," Research Policy, 43, $530-542$.

Manova, K. And Z. Zhang (2012): "Export Prices Across Firms and Destinations," The Quarterly Journal of Economics, 127, 379-436.

MAnsfield, E. (1986): "Patents and innovation: An empirical study," Management science, 32, 173-181.

Martínez, C. (2010): "Patent families: When do different definitions really matter?" Scientometrics, 86, 39-63.

Maskus, K. E. And M. Penubarti (1995): "How trade-related are intellectual property rights?" Journal of International Economics, 39, 227 - 248. 
Melitz, M. J. (2003): "The Impact of Trade on Intra-Industry Reallocations and Aggregate Industry Productivity," Econometrica, 71, 1695-1725.

Palangkaraya, A., P. H. Jensen, And E. Webster (2017): "The effect of patents on trade," Journal of International Economics, 105, 1-9.

Patel, P. And K. PAVitT (1997): "The technological competencies of the world's largest firms: Complex and path-dependent, but not much variety," Research Policy, 26, 141-156.

Sampat, B. N. (2018): "A Survey of Empirical Evidence on Patents and Innovation," Working Paper 25383, National Bureau of Economic Research.

Silva, J. S. And S. Tenreyro (2006): "The log of gravity," The Review of Economics and statistics, 88, 641-658.

Smith, P. J. (1999): "Are weak patent rights a barrier to U.S. exports?" Journal of International Economics, 48, 151 - 177.

SoEte, L. (1981): "A general test of technological gap trade theory," Weltwirtschaftliches Archiv, 117, 638-660.

(1987): "The impact of technological innovation on international trade patterns: The evidence reconsidered," Research Policy, 16, 101 - 130.

TeEce, D. J. (1986): "Profiting from technological innovation: Implications for integration, collaboration, licensing and public policy," Research Policy, 15, 285-305.

Van Beveren, I. And H. Vandenbussche (2010): "Product and process innovation and firms' decision to export," Journal of Economic Policy Reform, $13,3-24$.

WAKELIN, K. (1998a): "Innovation and export behaviour at the firm level," Research policy, 26, 829-841.

(1998b): "The role of innovation in bilateral OECD trade performance," Applied Economics, 30, 1335-1346. 


\section{A Sectoral distributions}

Table A1: Patents' distribution across sectors, firm level, 2011

\begin{tabular}{lrrrr}
\hline & obs. & mean & process & tech. intensity \\
\hline Aircraft and Spacecraft & 520 & 6.77 & 0.27 & 1 \\
Animals \& Animal Products & 1,823 & 0.03 & 0.35 & 4 \\
Chemicals \& Allied Industries & 5,004 & 2.19 & 0.42 & 2 \\
Electrical Machinery & 7,011 & 2.12 & 0.19 & 1 \\
Foodstuffs & 11,081 & 0.03 & 0.46 & 4 \\
Footwear \& Headgear & 1,101 & 0.36 & 0.05 & 4 \\
Metals & 6,713 & 0.35 & 0.22 & 3 \\
Mineral Products & 658 & 0.68 & 0.39 & 3 \\
Miscellaneous & 7,687 & 0.18 & 0.12 & 4 \\
Optical and Medical Instruments & 4,816 & 2.11 & 0.20 & 1 \\
Other Electrical Machinery & 13,432 & 0.66 & 0.19 & 2 \\
Pharmaceutical Products & 638 & 3.11 & 0.41 & 1 \\
Plastics and Rubber & 3,534 & 0.76 & 0.25 & 3 \\
Raw Hides, Skins, Leather, \& Furs & 1,183 & 0.03 & 0 & 3 \\
Ships and Boats & 326 & 0.33 & 0.03 & 3 \\
Stone \& Glass Products & 3,214 & 0.45 & 0.36 & 4 \\
Textiles & 6,414 & 0.06 & 0.11 & 2 \\
Transportation & 7,332 & 1.05 & 0.12 & 4 \\
Vegetable Products & 3,322 & 0.06 & 0.68 & 4 \\
Wood \& Wood Products & 6,356 & 0.14 & 0.27 & \\
Total & 92,165 & 0.75 & 0.24 & \\
\hline
\end{tabular}

Notes: The table reports the distribution of patents (applied for in the period 2002-2011) across sectors defined at the 2-digits level of the HS6 system. Col. 1-3 report: number of firms, average number of patents per firm, average share of process-related patents per firm. The last column classifies sectors according to their technology intensity (OECD definition): 1=High-tech; $2=$ Medium-high-tech; $3=$ Medium-low-tech; $4=$ Low-tech. 
Table A2: Patents' distribution across sectors, firm-product level, 2011

\begin{tabular}{lrrrrr}
\hline & obs. & mean & weight & process & tech. intensity \\
\hline Aircraft and Spacecraft & 1,826 & 2.85 & 1.19 & 0.16 & 1 \\
Animals \& Animal Products & 11,424 & 0.03 & 0.02 & 0.61 & 4 \\
Chemicals \& Allied Industries & 48,123 & 2.58 & 0.86 & 0.44 & 2 \\
Electrical Machinery & 69,885 & 1.17 & 0.39 & 0.16 & 1 \\
Foodstuffs & 31,762 & 0.04 & 0.01 & 0.50 & 4 \\
Footwear \& Headgear & 10,796 & 0.18 & 0.13 & 0.01 & 4 \\
Metals & 69,102 & 0.57 & 0.12 & 0.22 & 3 \\
Mineral Products & 4,976 & 0.75 & 0.33 & 0.49 & 3 \\
Miscellaneous & 35,125 & 0.25 & 0.13 & 0.06 & 4 \\
Optical and Medical Instruments & 36,784 & 1.23 & 0.45 & 0.22 & 1 \\
Other Electrical Machinery & 95,930 & 0.66 & 0.20 & 0.17 & 2 \\
Pharmaceutical Products & 3,254 & 4.10 & 1.50 & 0.39 & 1 \\
Plastics and Rubber & 36,257 & 0.78 & 0.24 & 0.28 & 3 \\
Raw Hides, Skins, Leather, \& Furs & 12,797 & 0.040 & 0.02 & 0.01 & 4 \\
Ships and Boats & 771 & 0.57 & 0.38 & 0.08 & 3 \\
Stone \& Glass Products & 19,920 & 0.78 & 0.20 & 0.33 & 3 \\
Textiles & 69,707 & 0.08 & 0.02 & 0.14 & 4 \\
Transportation & 23,227 & 1.98 & 0.42 & 0.10 & 2 \\
Vegetable Products & 21,870 & 0.08 & 0.02 & 0.66 & 4 \\
Wood \& Wood Products & 39,143 & 0.22 & 0.05 & 0.17 & 4 \\
Total & 642,679 & 0.77 & 0.24 & 0.24 & \\
\hline
\end{tabular}

Notes: The table reports the distribution of patents (applied for in the period 2002-2011) across sectors defined at the 2-digits level of the HS6 system. Col. 1-4 report: number of firms-products, average number of patents per firm-product, average weighted number of patents per firm-product, average share of process-related patents per firm-product.The last column classifies sectors according to their technology intensity (OECD definition): 1=Hightech; 2=Medium-high-tech; 3=Medium-low-tech; 4=Low-tech. 


\section{B Supplementary regressions}

Table B1: Across firms, within destination-products markets: accounting for firm fixed effects

\begin{tabular}{|c|c|c|c|c|c|c|}
\hline & $\begin{array}{c}(1) \\
\ln X_{f c p t}\end{array}$ & $\begin{array}{c}(2) \\
\ln \text { Quantity }_{f c p t}\end{array}$ & $\begin{array}{c}(3) \\
\ln \text { UnitValue }_{f c p t}\end{array}$ & $\begin{array}{c}(4) \\
\ln X_{f c p t}\end{array}$ & $\begin{array}{c}(5) \\
\ln \text { Quantity }_{f c p t}\end{array}$ & $\begin{array}{c}6) \\
\ln \text { UnitValue }_{f c p t}\end{array}$ \\
\hline \multicolumn{7}{|l|}{2002} \\
\hline$D_{P a t} t_{f c}$ & $\begin{array}{c}0.226^{* * *} \\
(0.035)\end{array}$ & $\begin{array}{c}0.223^{* * *} \\
(0.035)\end{array}$ & $\begin{array}{c}0.003 \\
(0.008)\end{array}$ & & & \\
\hline$D_{P a t} f p c$ & & & & $\begin{array}{c}1.025^{* * *} \\
(0.061)\end{array}$ & $\begin{array}{c}1.022^{* * *} \\
(0.058)\end{array}$ & $\begin{array}{c}0.003 \\
(0.011)\end{array}$ \\
\hline Firm FE & Yes & Yes & Yes & Yes & Yes & Yes \\
\hline Product-Country FE & Yes & Yes & Yes & Yes & Yes & Yes \\
\hline$N$ & 1501262 & 1501262 & 1501262 & 1501262 & 1501262 & 1501262 \\
\hline adj. $R^{2}$ & 0.369 & 0.555 & 0.775 & 0.374 & 0.558 & 0.775 \\
\hline$N$ clusters & 212 & 212 & 212 & 212 & 212 & 212 \\
\hline \multicolumn{7}{|l|}{2007} \\
\hline $\operatorname{DPat}_{f c}$ & $\begin{array}{c}0.235^{* * *} \\
(0.029)\end{array}$ & $\begin{array}{c}0.204^{* * *} \\
(0.029)\end{array}$ & $\begin{array}{c}0.030^{* * *} \\
(0.010)\end{array}$ & & & \\
\hline$D P a t_{f p c}$ & & & & $\begin{array}{c}0.995^{* * *} \\
(0.050)\end{array}$ & $\begin{array}{c}0.991^{* * *} \\
(0.047)\end{array}$ & $\begin{array}{c}0.005 \\
(0.010)\end{array}$ \\
\hline \multicolumn{7}{|l|}{2011} \\
\hline $\operatorname{DPat}_{f c}$ & $\begin{array}{c}0.255^{* * *} \\
(0.034)\end{array}$ & $\begin{array}{c}0.258 * * * \\
(0.037)\end{array}$ & $\begin{array}{l}-0.004 \\
(0.012)\end{array}$ & & & \\
\hline$D_{P a t} f p c$ & & & & $\begin{array}{c}1.018^{* * *} \\
(0.039)\end{array}$ & $\begin{array}{c}1.008^{* * *} \\
(0.038)\end{array}$ & $\begin{array}{c}0.009 \\
(0.008)\end{array}$ \\
\hline
\end{tabular}

Note. Table reports results of regressions at the firm-product-country level, using data on exports, quantity and unit value for years $2001,2007,2011$. Robust standard errors clustered at country level in parenthesis. ${ }^{*} p<0.10,^{* *}$ $p<0.05,{ }^{* * *} p<0.01$ 